\title{
ANALISIS KEBIJAKAN LINKAGE PROGRAM \\ LEMBAGA KEUANGAN SYARIAH DALAM RANGKA \\ PEMBERDAYAAN UKM DI INDONESIA
}

\author{
Siti Hamidah \\ Fakultas Hukum Universitas Brawijaya \\ Jl. MT. Haryono No. 169 Malang \\ Email: hamidah@ub.ac.id
}

\begin{abstract}
Linkage program is a program that connecting banks to small micro enterprises through microfinance institutions. The weakness of the Linkage program is the regulatory that are scattered in various regulation, and specifically for Islamic financial institutions the problems regard to compliance with the provisions of sharia. This research is based on statute and conceptual approach. The result from collecting and analysing the Linkage Program regulatory for Islamic Financial Institutions in Indonesian positive law show that the regulation of Linkage programs classified in two groups, the substance and procedural policies. These regulation becomes a reference for Islamic financial institutions, small and micro enterprises in Indonesia
\end{abstract}

Key words: linkage program, islamic financial institution, small micro enterprises

\begin{abstract}
Abstrak
Linkage program adalah program yang menghubungkan bank dengan pelaku usaha mikro kecil melalui lembaga keuangan mikro. Kelemahan dalam Linkage program adalah pada aspek peraturan yang tersebar dalam berbagai aturan, dan khusus bagi lembaga keuangan syariah terdapat pula kendala berkaitan dengan kesesuaian dengan ketentuan syariah. Dari penelitian dengan pendekatan perundang-undangan dan pendekatan konseptual ini diperoleh inventarisasi serta analisis kebijakan Linkage Program bagi Lembaga Keuangan Syariah dalam hukum positif Indonesia. Kebijakan terkait Linkage program, diklasifikasi dalam 2 kelompok, yaitu kebijakan substansi dan prosedural. Aturan inilah yang menjadi rujukan bagi lembaga keuangan syariah rangka pemberdayaan usaha kecil mikro di Indonesia.
\end{abstract}

Kata kunci: Linkage program, lembaga keuangan syariah, usaha mikro kecil

\section{Latar Belakang}

Usaha Mikro Kecil dan Menengah berperan dalam mendorong pertumbuhan ekonomi dan mewujudkan stabilitas nasional pada umumnya dan stabilitas ekonomi pada khususnya. Dari lingkup perspektif global, UMKM juga memainkan peran sangat vital dalam pembangunan dan pertumbukan ekonomi, tidak hanya di negara sedang berkembang, melainkan juga di negara maju. ${ }^{1}$

1 Tulus TH Tambunan, UMKM di Indonesia, Ghalia Indonesia, 2009, hlm. 1. 
Mengingat peran penting UMKM bagi perekonomian nasional, terutama dari perspektif kesempatan kerja, pengentasan kemiskinan serta pembangunan ekonomi regional, adalah suatu yang wajar apabila pemerintah berpihak pada UMKM.Akan tetapi sampai saat ini keberpihakan tersebut secara umum masih belum mampu menunjukan hasil yang sesuai dengan harapan. Berbagai kendala klasik baik dari sisi internal (teknis produksi) maupun sisi eksternal (bisnis) masih sering dijumpai. ${ }^{2}$

Berkaitan dengan pelaksanaan pemberdayaan UMKM di Indonesia, beberapa lembaga dan instansi saling bekerjasama untuk mewujudkannya. Bank Indonesia melakukannya melalui financial assistance (pemberian Kredit Likuiditas Bank Indonesia) dan technical assistance yang dilakukan sejak tahun 1960, selanjutnya dengan diberlakukannya UU No.23 Tahun 1999 sebagaimana telah diubah dengan UU No.3 Tahun 2004, peranan BI menjadi bersifat tidak langsung dan lebih terfokus pada bantuan teknis (technical assistance). ${ }^{3}$

Pemberdayaannya melibatkan bank komersial, baik bank umum maupun bank perkreditan rakyat, yang beroperasi secara konvensional maupun berdasar prinsip syariah. Sesuai hasil temuan World Bank, pendekatan yang paling tepat adalah dengan Lembaga Keuangan Mikro sehingga linkage program bank dengan Lembaga Keuangan Mikro harus dioptimalkan untuk menjangkau UMKM. Hal ini sesuai pula dengan program Arsitektur Perbankan Indonesia (API) di tahun 2004. ${ }^{4}$ Penelitian yang dilakukan oleh Sukarmi dkk, juga memberikan saran Lingkage Program, karena akan memberikan nilai tambah baik bagi BPR maupun usaha mikro dan kecil pada umumnya, serta meningkatkan market share bank umum dalam penyaluran kredit kepada usaha mikro dan kecil karena lokasi BPR yang mudah terjangkau dan tersebar hampir di setiap daerah di Indonesia. ${ }^{5}$

Linkage program merupakan kerjasama yang dilaksanakan bank umumkepadalembaga keuangan mikro dalam bentuk pembiayaan sebagai upaya untuk meningkatkan kegiatan usaha kecil mikro (UKM). ${ }^{6}$ Melalui program ini dibuat perjanjian kerjasama penyaluran pembiayaan antara pihak, bank umum, lembaga keuangan mikro (BPR, BMT, atau Koperasi) kepada UKMUMKM yang akan menguntungkan masing-masing pihak. Pihak bank umum

2 Sukarmi dkk, Analisis Potensi Bisnis UKM Jawa Timur dalam Rangka Menghadapi Integrasi Pasar Asean, Bank Indonesia dan Lembaga Riset Perbankan Jawa Timur (LRPD), 2007.

3 Bank Indonesia, Booklet Perbankan Syariah 2009, hlm. 58.

4 Siti Maesaroh, Efektivitas Linkage Program Bank Syariah Mandiri dalam Penguatan Pembiayaan Lembaga Keuangan Mikro, Skripsi, Fakultas Syariah dan Hukum, Universitas Islam Negeri Syarif Hidayatullah, Jakarta, 2011, hlm. 33.

5 Sukarmi, Gozali Maskie, Adi Kusumaningrum, Perdana Rahadian, Analisis Potensi Bisnis UKM Jawa Timur dalam Rangka Menghadapi Integrasi Pasar Asean, 2007.

6 Evis Amalia, Keadilan Distributif dalam Islam, RajaGrafindo Persada, Jakarta, 2009, hlm. 307, dalam Siti Maesaroh, Ibid. 
diuntungkan dengan penyerapan dana pembiayaan yang tersalurkan kepada UMKM melalui lembaga keuangan mikro, adapun lembaga keuangan mikro dapat memperoleh sumber dana pembiayaan dari bank umum, demikian pula pelaku usaha kecil yang selama ini dianggap tidak bankable, dapat memperoleh pembiayaan perbankan.

Pada lembaga keuangan syariah, pelaksanaan yang dilakukan oleh Bank Syariah melalui program-program strategis. Keberadaan Lembaga Keuangan Mikro Syariah seperti BMT sebagai mediasi antara sektor UMKM dengan pihak Bank Syariah diperlukan, karena selaras dengan kebutuhan UMKM. Sehingga BMT sebagai kepanjangan tangan Bank Syariah dapat menyalurkan pembiayaan tanpa kekhawatiran Bank Syariah menanggung resiko yang sangat besar. Melalui project pemberdayaan UMKM sekaligus pengembangan skema atau model investasi syariah untuk UMKM. Bank Syariah dapat langsung menangani pembiayaan bagi hasil (mudharabah dan musyarakah) dengan sistem tanggung renteng. ${ }^{7}$

Dari penelitian yang dilakukan oleh Maesaroh dapat disimpulkan Lembaga keuangan mikro yang menjalankan linkage program telah mengalami peningkatan, tetapi tetap ada catatan, antara lain kepada Bank Indonesia (yang disaat penelitian dilakukan sebagai pemegang kebijakan di bidang perbankan), berkaitan dengan standart penilaian kelayakan. ${ }^{8}$ Dari hasil penelitian di atas dapat diketahui bahwa linkage program ini masih belum optimal. Salah satunya adalah berkaitan dengan aspek pengaturannya, khususnya pada landasan yuridis. Ketiadaan dasar hukum yang jelas atas linkage program, menjadikan program ini tersebar dalam berbagai peraturan, yang sangat dimungkinkan terjadinya tumpang tindih dan inkonsistensi antar peraturan.

Penelitian terkait dengan kelemahan pengaturan tentang UMKM telah dilakukan oleh Sihabudin dkk. Penelitian menunjukkan peraturan dan kebijakan yang menghambat pembiayaan usaha kecil masih belum dibuat secara komprehensif dengan melibatkan para stakeholders yang terkait dengan pengembangan Usaha Kecil. Peraturan yang ada masih bersifat ego sektoral belum adanya koordinasi yang maksimal dalam penyusunan peraturan ataupun kebijakan pembiayaan terhadap Usaha Kecil. Sehingga disarankan restrukturisasi sistem keuangan publik bagi usaha kecil serta mengembangkan kredit khusus bagi usaha kecil untuk membantu dari segi pendanaan. Diperlukan koordinasi dan kerjasama yang baik secara sinergi antara Pemerintah, Lembaga Perbankan, Perguruan Tinggi dan Lembaga Swadaya Masyarakat serta masyarakat umum dalam rangka melakukan pembinaan terhadap Usaha Kecil. ${ }^{9}$

7 Ekonomi Islam, Menjadi Bank Syariah yang Ramah UMKM, http://ekisopini.blogspot.com/2009/08/ menjadi-bank-syariah-yang-ramah-umkm_4496.html, diakses 23 April 2014 pukul 12.33 WIB.

8 Siti Maesaroh, Ibid.

9 Sihabudin, Sukarmi, Hamidah, dan Kusumaningrum, Evaluasi Peraturan Perbankan yang Menghambat Pembiayaan Usaha Kecil di Jawa Timur, 2006. 
Selain masalah di atas, khususnya berkaitan dengan linkage program yang dijalankan oleh perbankan syariah, memerlukan perhatian khusus yaitu dalam hal perjanjian atau akad yang dilakukan, agar sesuai dengan prinsip syariah. Penelitian yang dilakukan oleh Hamidah, berangkat dari isu hukum atas kesesuaian penggunaan akad yang dilakukan antara bank umum syariah kepada lembaga keuangan mikro syariah yang akan menyalurkan pembiayaan kepada nasabahnya. Dari penelitian ini dibutuhkan adanya kebijakan untuk menyusun landasan hukum yang kuat bagi lembaga keuangan syariah dalam menyalurkan dananya melalui pembiayaan multiakad (dalam hal ini untuk linkage program). Karena tanpa adanya landasan yang kuat berpotensi melahirkan akad yang tidak sesuai dengan hukum Islam. ${ }^{10}$.

Berangkat dari uraian dia atas penting dilakukan kajian untuk menginventarisir, menganalisis kebijakan pengaturan Linkage Program bagi Lembaga Keuangan Syariah dalam hukum positif Indonesia yang ideal baik secara substansi maupun prosedural, sebagai rujukan bagi lembaga keuangan syariah rangka pemberdayaan Usaha Mikro Kecil Menengah di Indonesia.

\section{Pembahasan}

Linkage program baru dicanangkan pada tahun 2004 dengan adanya Arsitektur Perbankan Indonesia (selanjutnya disingkat
API), sebagai salah satu program bagi Bank Perkreditan Rakyat (BPR) dalam menghadapi persaingan yang ketat dan memperkuat daya saing adalah dengan kebijakan Linkage Program. Dalam rangka kerjasama antara Bank Umum (BU) dan BPR maka dikeluarkanlah Generic Model Linkage Program sebagai salah satu program API. Adanya Generic Model Linkage Program memperjelas aturan main Linkage Program. Antara lain, adanya persyaratan minimum BPR peserta linkage; munculnya tiga skim linkage yaitu executing, channeling, dan joint financing; serta kode etik peserta linkage. Linkage Program ini dilandasi semangat kemitraan yang bersifat symbiosis mutualistic dengan tetap berorientasi pada aspek bisnis yang tertuang dalam Generic Model Linkage Program.

API memang belum memuat dengan detil berbagai peraturan perundang-undangan sebagai dasar pengaturan pelaksanaan Linkage Program, karena memang API diibaratkan sebagai "GBHN" bagi dunia perbankan, yang memuat arah yang akan dituju bagi dunia perbankan di Indonesia dalam periode tertentu.

\section{A. Linkage Program bagi Perbankan Syariah}

Khusus program API bagi Bank Syariah, dalam Cetak Biru API Tahun 2005 diterapkan dengan berpedoman pada inisiatif strategis yang tertuang dalam Cetak 
Biru Pengembangan Perbankan Syariah di Indonesia. Pelaksanaan inisiatif strategis ini difokuskan pada empat area pengembangan, yaitu kepatuhan pada Prinsip Syariah, ketentuan kehati-hatian, efisiensi operasi dan daya saing serta kestabilan sistem dan kemanfaatan bagi perekonomian.

Dalam rangka pelaksanaan isu strategis, telah diterbitkan berbagai peraturan, antara lain Peraturan Bank Indonesia (PBI) No. 7/13/ PBI/2005 tentang Kewajiban Penyediaan Modal Minimum Bank Umum Berdasarkan Prinsip Syariah (KPMM), PBI No. 7/24/ PBI/2005 tanggal 3 Agustus 2005 tentang Fasilitas Pembiayaan Jangka Pendek Syariah (FPJPS), PBI No. 7/35/PBI/2005 tanggal 29 September 2005 sebagai amandemen atas PBI No. 6/24/PBI/2004 tentang Bank Umum Syariah (BUS), serta PBI No. 7/33/PBI/2005 September 2005 tentang Perubahan PBI No. 5/17/PBI/2003 tentang Persyaratan Tata Cara Pelaksanaan Jaminan Pemerintah Terhadap Kewajiban Pembayaran BPR.

Walau belum ada satu ketentuan khusus berkaitan dengan Linkage Program yang dituangkan dalam sebuah PBI, akan tetapi berkaitan dengan Linkage Program bagi bank syariah telah disusun Generic Model Linkage Program (Antara Bank Umum Syariah (BUS)/Unit Usaha Syariah (UUS) dengan Bank Pembiayaan Rakyat Syariah (BPRS).

Pola dan skim yang ditawarkan bagi perbankan syariah yang akan melaksanakan Linkage Program tidak jauh berbeda dengan bank konvensional, yaitu dengan skim executing, channeling, dan joint financing. Beberapa ketentuan dalam Generic Model Linkage Program untuk perbankan syariah yang disarikan oleh Maesaroh adalah: terkait dengan pola, mencakup pola executing distribusi pendapatan sesuai dengan nisbah yang disepakati, pada pola channeling, bank syariah (BUS/UUS) dapat memperoleh nisbah bagi hasil/margin, adapun pada pola joint financing bank syariah memperoleh dari nisbah dengan Lembaga Keuangan Mikro (LKM) maupun nisbah/margin dengan LKM. Selain itu juga diatur tentang nisbah, target, batas plafond, jaminan dan jangka waktu perjanjian. ${ }^{11}$

Dalam pola executing, BUS akan menyalurkan kepada Lembaga Keuangan Mikro (LKM), baik itu BPR, Koperasi, BMT atau lainnya, untuk selanjutnya disalurkan kepada UKM, dimana keputusan siapa calon mitra (UKM) berada di tangan LKM. Sebagai konsekwensi dari keputusannya.

Apabila digambarkan, maka skim executing adalah sebagai berikut: (Gambar 1)

Akad mudha rabah ini merupakan suatu bentuk Equity Financing, penyandang dana adalah BU/UUS dan LKM bertindak sebagai entreneur/mudharib. Secara teknis, pihak pertama (shahibul maal) menyediakan seluruh $(100 \%)$ modal, sedangkan pihak kedua menjadi pengelola. Keuntungan usaha secara mudharabah dibagi menurut kesepakatan yang digunakan dalam kontrak, sedangkan 


\section{Gambar 1: Skim Executing pada Linkage Program}

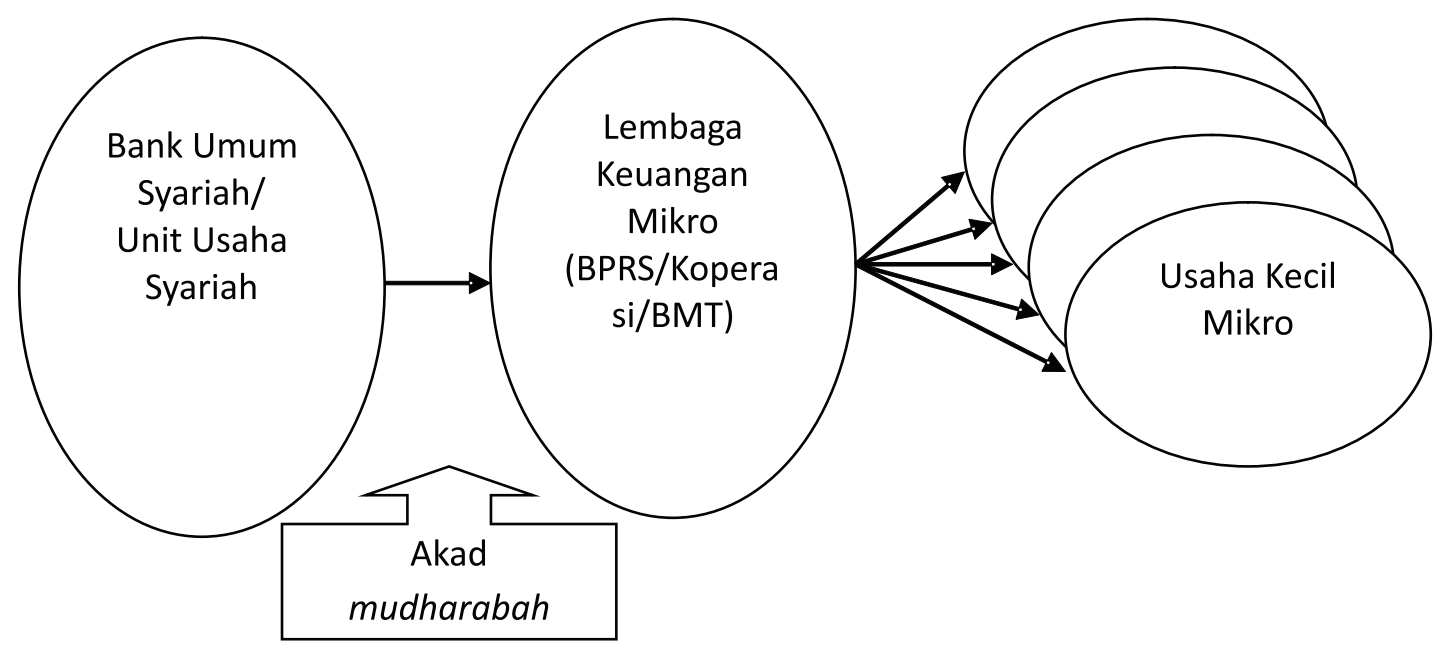

\section{Sumber: Bahan Hukum, diolah, 2014}

apabila rugi ditanggung oleh pemilik modal selama kerugian itu bukan akibat kelalaian si pengelola. Atas dasar inilah, maka pihak BUS/UUS tidak bertanggungjawab atas permasalahan dalam pembiayaan kepada UKM.

Dasar hukum bagi pelaksanaan akad mudharabah, selain bersumber kepada Al-Quran juga berdasar pada hadist dan ijtihad. Dalam hukum positif Indonesia, ketentuan khusus tentang mudharabah telah tertuang dalam UU Perbankan Syariah No. 21 Tahun 2008, khususnya pasal 1 angka 25 yang menyebutkan bahwa pembiayaan yaitu penyediaan dana atau tagihan yang dipersamakan dengan itu, salah satunya adalah berupa transaksi bagi hasil dalam bentuk mudharabah dan musyarakah, selain yang tertuang dalam UU, dalam PBI juga diatur tentang mudharabah, antara lain adalah PBI No. 7/46/PBI/2005 tentang Akad penghimpunan dan penyaluran Dana Bagi Bank yang Melaksanakan Kegiatan Usaha Berdasarkan Prinsip Syariah, juga dalam PBI No.: 9/19/PBI/2007 tentang Pelaksanaan Prinsip Syariah dalam Kegiatan penghimpunan dana dan penyaluran Dana Serta Pelayanan Jasa Bank Syariah. Selain PBI, pengaturan tentang mudharabah juga terdapat dalam berbagai aturan lain, misalnya dalam Kompilasi Hukum Ekonomi Syariah, yang menjadi pedoman hakim Pengadilan Agama dalam memutus sengketa ekonomi syariah.

Pola kedua adalah channeling. Pada channeling BUS/UUS akan memberikan langsung pembiayaan kepada UKM. Sehingga risiko ditanggung oleh BUS/UUS. Dengan demikian kewenangan LKM hanyalah sebatas yang diberikan oleh BUS/UUS, LKM tidak memiliki kewenangan memutus pembiayaan kecuali setelah adanya kuasa yang diberikan oleh BUS/UUS. Dasar yang dipergunakan adalah akad Wakalah. Adapun akad antara LKM dengan UKM disesuaikan dengan kebutuhan UKM, dengan tetap memperhatikan pasal 2 PBI tentang akad. 
BUS/UUS mendapatkan pendapatan dari nisbah bagi hasil/margin yang disepakati, sedang LKM mendapatkan upah/fee yang besarnya disepakati antara BUS/UUS dengan LKM. Dalam beberapa literatur, disebutkan akad wakalah pada umumnya dipergunakan sebagai akad yang membantu dalam pelaksanaan akad utama. Gambar 2 adalah gambaran skim channeling.

Pola ketiga, adalah joint financing. Jenis akad yang dipergunakan adalah Musyarakah atau Joint Venture Profit Sharing. Melalui kontrak ini, dua pihak atau lebih (dalam hal ini adalah BUS/UUS dan LKM) mengumpulkan modal untuk membiayai UKM. Dalam PBI No. 7/46/PBI/2005 disebutkan Musyarakah adalah transaksi penanaman dana dari dua atau lebih pemilik dana dan/atau barang untuk menjalankan usaha tertentu sesuai syariah dengan pembagian hasil usaha antara kedua belah pihak berdasarkan nisbah yang disepakati, sedangkan pembagian kerugian berdasarkan proporsi modal masing-masing. Berikut adalah skema kontrak ketiga.

Khusus berkaitan dengan Linkage Program, kode etik yang harus dipatuhi para pihak, adalah sebagai berikut: ${ }^{12}$

1. BUS/UUS yang melakukan kerjasama linkage program dengan BPRS, tidak diperbolehkan mengambil alih pembiayaan terhadap nasabah BPRS yang sedang dibiayai melalui linkage program dan atau masih menjadi nasabah BPRS.

2. Bagi nasabah BPRS yang telah naik kelas (dari nasabah mikro menjadi kecil) dan memerlukan dana pembiayaan yang lebih beasr, namun BPRS tidak mampu membiayai karena kendala BMPK maka BUS/UUS dapat membiayai nasabah BPRS dimaksud.

3. BUS/UUS yang melakukan linkage program dengan BPRS, tidak diperbolehkan mengambil sumber daya manusia BPRS.

\section{Gambar 2: Skim Channeling pada Linkage Program}

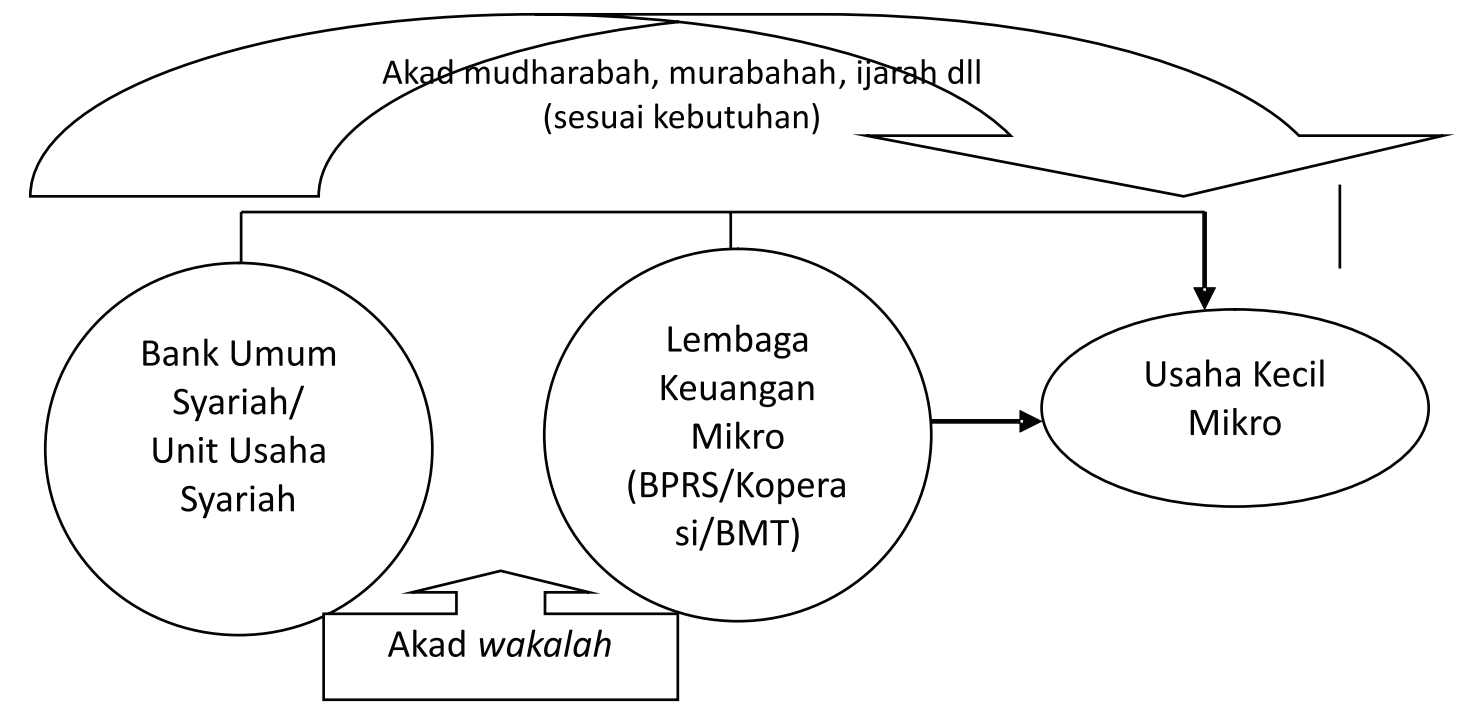

Sumber: Bahan Hukum, diolah, 2014

12 Bank Indonesia,Generic Model Linkage Program, (Antara BUS/UUS dengan BPRS), Bank Indonesia, tanpa tahun, hlm. 15. 
Gambar 3. Skim Joint Financing pada Linkage Program

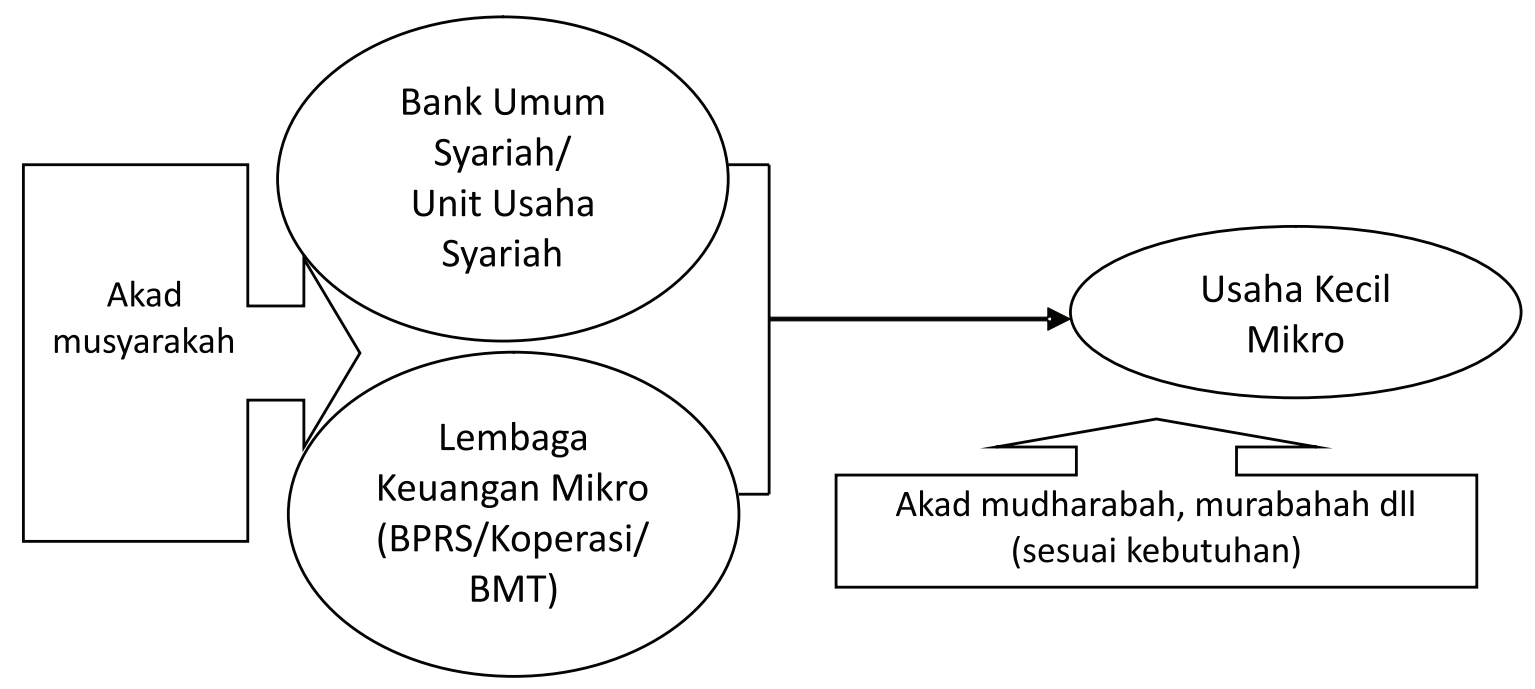

Sumber: Bahan Hukum, diolah, 2014

4. BUS/UUS dan BPRS harus trasparan dalam memberikan dan menyampaikan informasi yang terkait dengan linkage program sejauh tidak melanggar ketentuan yang berlaku (seperti laporan keuangan struktur pendanaan dan company profile).

5. Bagi BPRS, satu jaminan hanya dijaminkan kepada satu shohibul maal mitra pembiayaan (BUS/UUS).

6. BUS/UUS tidak diperkenankan untuk memanfaatkan data nasabah pembiayaan dan BPRS untuk kepentingan di luar linkage program.

7. BUS/UUS dan BPRS yang melaksanakan linkage program dengan pola joint financing dan channeling, tidak diperkenankan membebani nasabah pembkiayaan dengan margin/nisbah bagi hasil yang lebih tinggi dari harga pasar untuk sektor usaha UMK yang dibiayai.

8. BUS/UUS yang melakukan linkage program dengan BPRS, tidak diperkenankan meminta laporan hasil pemeriksaan yang dikeluarkan oleh Bank Indonesia.
9. BPRS yang mengikuti linkage program harus memelihara tingkat kesehatannya.

10. Setiap pelanggaran kode etik di atas oleh BUS/UUS/BPRS dilaporkan kepada Bank Indonesia oleh pihak yang merasa dirugikan.

Dalam membantu perkembangan linkage program, BI telah mengeluarkan kebijakan antara lain yaitu: ${ }^{13}$

1. Penyediaan informasi jinerja $\mathrm{BPR} / \mathrm{S}$ (LKM) yang akan menjadi calon peserta linkage program.

2. Perlakuan khusus dalam penilaian kolektibilitas bagi BUK/BUS/UUS yang menggunakan channeling.

3. Pertimbangan kemudahan pembukuan jaringan kantor cabang bagi BPR/S (LKM).

4. Penyediaan fasilitas infrastruktur pendukung antara lain pelaporan BPR/S (LKM) ke BI secara online.

5. Keikutsertaan dalam workshop terkait kebijakan linkage program. 


\section{B. Analisis Kebijakan Linkage Program Melalui Koperasi}

Linkage Program melalui koperasi adalah program kerjasama antara bank umum termasuk bank umum peserta KUR dengan koperasi dalam rangka meningkatkan akses pembiayaan UKM. Tidak ada pengaturan secara khusus tentang linkage program dalam UU Koperasi No. 25 Tahun 1992. Tetapi ada beberapa pasal yang terkait, misalnya pasal 43 dan 44 yang mengatur tentang lapangan usaha, yang jika ditafsirkan secara luas, maka kegiatan koperasi yang berperan di segala kehidupan ekonomi rakyat termasuk di dalamnya berperan dalam pemberdayaan UKM.

Bank Indonesia memiliki komitmen berkaitan dengan Koperasi. Bersama dengan Kementrian Negara Koperasi dan Usaha Kecil, dan Menengah untuk mengatur kebijakan linkage program dalam bentuk Generic Model Linkage Program antara bank umum dengan koperasi.

Dalam rangka pelaksanaan Linkage Program ini, maka telah diterbitkan Peraturan Menteri Negara Koperasi dan Usaha Kecil dan Menengah Republik Indonesia. Nomor: 03/Per/M.KUKM/III/2009 Tentang: Pedoman Umum Linkage Program Antara Bank Umum Dengan Koperasi.

Tidak berbeda dengan yang tertuang dalam API, dalam peraturan ini juga dikenal 3 pola linkage program, yaitu melalui executing, channeling dan joint financing. Hanya dalam klausula pengertian pihak LKM ditentukan dan disebutkan dengan tegas, yaitu Koperasi. Dalam peraturan ini dibedakan antara Koperasi konvensional dan syariah, berikut adalah yang berkaitan dengan koperasi syariah.

Yang dimaksud dengan koperasi dalam peraturan ini juga dijelaskan dengan rinci, mulai pengertian Koperasi secara umum, Koperasi simpan pinjam, Unit Simpan Pinjam, serta Koperasi Jasa Keuangan Syariah dan Unit Jasa Keuangan Syariah Koperasi, sampai pengertian koperasi dalam rangka Linkage Program.

Dalam rangka linkage program, pada 3 (tiga) pola. Yaitu: ${ }^{14}$

1. Executing: Pinjaman yang diberikan oleh bank umum kepada koperasi dalam rangka pinjaman/pembiayaan untuk disalurkan kepada anggota Koperasi. Pencatatan di Bank Umum sebagai pinjaman kepada Koperasi, sedangkan pencatatan di koperasi sebagai pinjaman kepada anggota koperasi.

2. Channeling: Pinjaman yang diberikan oleh bank umum kepada anggota koperasi melalui koperasi yang bertindak sebagai agen dan tidak mempunyai kewenangan memutus kredit kecuali mendapat surat kuasa dari Bank Umum. Pencatatan di Bank Umum sebagai pinjaman kepada anggota koperasi, sedangkan pencatatan di Koperasi pada off balance sheet.

3. Joint Financing: Pembiayaan bersama oleh bank umum dan koperasi terhadap anggota koperasi. Pencatatan outstanding credit bagian Bank Umum dan bagian Koperasi sebesar porsi pembiayaan kepada anggota koperasi. 
Tabel 1. 3 (tiga) Pola Linkage Program melalui Koperasi Syariah

\begin{tabular}{|c|c|}
\hline Pola & Koperasi Syariah \\
\hline Executing & $\begin{array}{l}\text { - Risiko pembiayaan kepada anggota koperasi, apabila kegagalan pembiayaan karena } \\
\text { kerugian bisnis secara normal (normal business loss), maka risiko ditanggung oleh } \\
\text { KJKS/UJKS-Koperasi; } \\
\text { - Distribusi pendapatan, sesuai dengan nisbah yang disepakati antara BUS/UUS dan } \\
\text { KJKS/UJKS-Koperasi; } \\
\text { - Penentuan besarnya nisbah bagi hasil/margin bagi anggota koperasi, merupakan } \\
\text { kesepakatan bersama dengan mempertimbangkan harga pasar untuk sektor/bidang } \\
\text { usaha UMK yang dibiayai; } \\
\text { - Jaminan, sesuai Undang-undang Perbankan dan ketentuan perbankan yang berlaku; } \\
\text { - Jaminan anggota Koperasi, sesuai yang dipersyaratkan KJKS/UJKS-Koperasi; } \\
\text { Akad Pembiayaan kepada anggota koperasi, dilakukan oleh KJKS/UJKS-Koperasi; } \\
\text { Jangka waktu proses persetujuan kredit dalam rangka Linkage Program, maksimal } 1 \\
\text { (satu) bulan setelah data dan persyaratan dipenuhi secara lengkap. }\end{array}$ \\
\hline Channeling & $\begin{array}{l}\text { - Risiko pembiayaan kepada anggota koperasi, apabila kegagalan pembiayaan karena } \\
\text { kerugian bisnis secara normal (normal business loss), maka risiko ditanggung oleh } \\
\text { BUS/UUS; } \\
\text { - Distribusi pendapatan: } \\
\text { BUS/UUS memperoleh pendapatan dari nisbah bagi hasil/margin yang disepakati } \\
\text { dengan UMK; } \\
\text { KJKS/UJKS-Koperasi mendapatkan fee yang besarnya disepakati antara BUS/UUS } \\
\text { dengan KJKS/UJKS-Koperasi; } \\
\text { - Penentuan besarnya nisbah bagi hasil/margin bagi anggota Koperasi, merupakan } \\
\text { kesepakatan bersama dengan mempertimbangkan harga pasar untuk sektor/bidang } \\
\text { usaha UMK yang dibiayai; } \\
\text { - Jaminan anggota Koperasi, sesuai Undang-undang Perbankan dan ketentuan } \\
\text { perbankan yang berlaku; } \\
\text { - Akad pembiayaan kepada anggota Koperasi, dilakukan oleh KJKS/UJKS-Koperasi } \\
\text { untuk dan atas nama BUS/UUS; } \\
\text { - Jangka waktu proses persetujuan kredit dalam rangka Linkage Program, maksimal } 1 \\
\text { (satu) bulan setelah data dan persyaratan lengkap dipenuhi. }\end{array}$ \\
\hline $\begin{array}{l}\text { Joint } \\
\text { Financing }\end{array}$ & $\begin{array}{l}\text { - Risiko pembiayaan kepada anggota Koperasi, apabila kegagalan pembiayaan karena } \\
\text { kegagalan bisnis secara normal (normal business loss), maka risiko ditanggung } \\
\text { bersama antara BUS/UUS dan KJKS/UJKS-Koperasi sesuai dengan porsinya; } \\
\text { - Distribusi pendapatan: } \\
\text { BUS/UUS memperoleh pendapatan dari nisbah bagi hasil/margin yang disepakati } \\
\text { dengan UMK; } \\
\text { Pembagian pendapatan antara BUS/UUS dengan KJKS/UJKS-Koperasi sesuai } \\
\text { dengan porsi yang disepakati; } \\
\text { - Penentuan besarnya nisbah bagi hasil/margin bagi anggota Koperasi, merupakan } \\
\text { kesepakatan bersama dengan mempertimbangkan harga pasar untuk sektor/bidang } \\
\text { usaha UMK yang dibiayai; } \\
\text { - Jaminan anggota Koperasi, sesuai Undang-undang Perbankan dan ketentuan } \\
\text { perbankan yang berlaku; } \\
\text { - Akad kredit kepada anggota Koperasi, dilakukan oleh KJKS/UJKS-Koperasi untuk } \\
\text { dan atas nama BUS/UUS; } \\
\text { - Jangka waktu proses persetujuan kredit dalam rangka Linkage Program, maksimal } 1 \\
\text { (satu) bulan setelah data dan persyaratan lengkap dipenuhi. }\end{array}$ \\
\hline
\end{tabular}


Perjanjian yang dibuat dapat dilakukan melalui kredit, pembiayaan maupun pembiayaan berdasarpolasyariah.Pembiayaan dengan pola syariah yang dimaksud adalah menggunakan Hukum Islam sebagai dasar perjanjian, misalnya dengan pola bagi hasil, jual beli, sewa dll. Tidak berbeda dengan ketentuan perbankan yang berdasar kepada UU Perbankan dan PBI No. 7/46/PBI/2005 tentang Akad penghimpunan dan penyaluran Dana Bagi Bank yang Melaksanakan Kegiatan Usaha Berdasarkan Prinsip Syariah, pada koperasi yang menjalankan linkage program dia juga tunduk kepada dua aturan di atas, karena koperasi di sini berkedudukan sebagai LKM yang menerima pembiayaan dari bank dan selanjutnya disalurkan kepada UKM. Dengan demikian secara substantif, berbagai peraturan berkaitan dengan linkage program ini tidak berbeda dengan aturan sebelumnya, hanya menyebut dengan jelas bahwa LKM yang dimaksud adalah koperasi, yang dapat berbentuk KSP/USP-Koperasi atau KJKS/ UJKS-Koperasi.

Dalam menentukan koperasi yang dapat mengikuti linkage program akan dilakukan identifikasi. Identifikasi koperasi calon peserta Linkage Program dilakukan oleh Kementerian Negara Koperasi dan Usaha Kecil dan Menengah, Dinas/Badan yang membidangi Koperasi dan Usaha Kecil dan Menengah, Bank Umum, Instansi terkait dan Lembaga Kemasyarakatan lainnya. Selanjutnya dibedakan pula yaitu peserta KUR (UKM Kredit Usaha Rakyat (selanjutnya disingkat
KUR)) dan Non-KUR, dan perbedaan antara bank umum konvensional dan pola syariah. Berikut adalah persyaratan kriteria koperasi dengan bank umum untuk UKM Non KUR yang menggunakan pola konvensional maupun pola syariah. ${ }^{15}$

1. Sudah berbadan hukum minimal 2 (dua) Tahun;

2. Minimal Cukup Sehat selama 2 (dua) tahun berturut-turut;

3. Sisa Hasil Usaha (SHU) selama 2 (dua) tahun terakhir positif;

4. Koperasi dengan outstanding pinjaman yang diberikan diatas Rp.1.000.000.000,00 (satu milyar rupiah) wajib diaudit oleh Akuntan Publik atau Koperasi Jasa Audit, dan dumumkan kepada anggotanya;

5. Non Performing Loan (NPL) maksimum $5 \%$ (lima per seratus);

6. Mempunyai anggota tetap dan/atau calon anggota minimal sebanyak 100 orang.

Adapun untuk pola syariah, persyaratan bagi koperasi adalah:

1. Telah menggunakan sistem syariah;

2. Pengikatan menggunakan akad syariah;

3. Sudah berbadan hukum minimal 2 (dua) Tahun;

4. Bagi hasil selama 2 (dua) tahun terakhir positif;

5. Koperasi dengan outstanding pembiayaan yang diberikan di atas Rp.1.000.000.000,00 (satu milyar rupiah) wajib diaudit oleh akuntan publik atau Koperasi Jasa Audit, dan diumumkan kepada anggotanya;

6. Non Performing Financing (NPF) maksimum $5 \%$ (lima per seratus);

7. Mempunyai anggota tetap dan/atau calon anggota minimal sebanyak 100 orang. 
Tidak ada perbedaan mendasar antara pola konvensional dan pola syariah dalam hal persyaratan koperasi yang menyalurkan kepada UKM Non-KUR, kecuali prinsip dasar pada koperasi harus menggunakan sistem syariah berikut akad yang dipergunakan dalam penyalurannya.

Selanjutnya diatur pula persyaratan kriteria koperasi dengan bank umum untuk UKM KUR tidak ada pembedaan baik yang menggunakan pola konvensional maupun pola syariah, yaitu: ${ }^{16}$

1. Telah memiliki badan hukum;

2. Telah melakukan usaha simpan pinjam secara aktif minimal 6 (enam) bulan;

3. Memiliki pengurus yang dipilih oleh anggota;

4. Memiliki AD/ART, minimal aturan tertulis;

5. Pengurus bersedia bertanggung jawab atas pinjaman yang diterima dan/atau disalurkan melalui koperasi kepada anggotanya;

6. Mempunyai usaha yang layak untuk dibiayai;

7. Tidak memiliki tunggakan kredit/ pembiayaan di bank maupun lembaga keuangan lainnya.

Penekanan pada persyaratan bagi Koperasi yang menyalurkan UKM KUR ditekankan pada prinsip kehati-hatian, karena peserta KUR telah memiliki kewajiban sebelumnya yang juga harus diselesaikan. Beberapa ketentuan kehati-hatian sebagaimana berikut: ${ }^{17}$

1. Besar kredit/pembiayaan yang dapat disalurkan kepada Peserta Linkage Program dengan Bank Umum sesuai

16 Ibid.

17 Ibid. kesepakatan, sedangkan dengan Bank Umum peserta KUR diberikan sampai dengan maksimal Rp. 500 juta dan kepada anggotanya maksimal Rp. 5 juta;

2. Jenis kredit/pembiayaan dan Jangka waktu permohonan sesuai kesepakatan dengan Bank Umum, sedangkan dengan Bank Umum peserta KUR Jenis kredit/ pembiayaan diperuntukan bagi modal kerja dan jangka waktu maksimal 3 (tiga) tahun;

3. Suku bunga kredit/pembiayaan sesuai kesepakatan dengan Bank Umum, sedangkan Suku bunga kredit/ pembiayaan dengan Bank Umum peserta KUR maksimal $16 \%$ (enam belas per seratus) efektif/ per tahun;

4. Biaya administrasi dan provinsi kredit/ pembiayaan dari Bank Umum peserta KUR tidak dipungut;

5. Koperasi peserta Linkage Program wajib menyampaikan laporan realisasi penyaluran kredit/pembiayaan kepada anggotanya paling lambat 5 (lima) hari kerja sejak tanggal penarikan.

Dalam Peraturan Menteri Negara Koperasi dan Usaha Kecil dan Menengah Republik Indonesia. Nomor: 03/Per/M.KUKM/III/2009 Tentang: Pedoman Umum Linkage Program Antara Bank Umum Dengan Koperasi ini tidak ada satu ketentuan tentang sanksi bagi pihak yang tidak mematuhinya. Walau demikian dalam peraturan ini dicantumkan kode etik, berisi hal-hal yang haris dipatuhi oleh para pihak, bagi koperasi syariah, aturan yang harus dipatuhi antara lain adalah tentang: 1).Kewajiban bagi bank untuk tetap memperhatikan prinsip-prinsip pemberian 
kredit yang sehat, apabila terdapat kenaikan kelas bagi anggota/mitra pembiayaan KJKS/ UJKS (dari debitur mikro menjadi kecil) dan memerlukan dana pembiayaan yang lebih besar, namun KJKS/UJKS-Koperasi tidak mampu membiayai. Kode etik ini sebenarnya sama dengan ketentuan dalam Generic Linkage Program Bank Indonesia dalam rangka API, yang perlu diperhatikan adalah penggunaan istilah yang tidak tepat, yaitu pada kata "kredit yang sehat", karena istilah kredit hanya melekat pada lembaga keuangan konvensional yang menggunakan perangkat bunga. 2).Kewajiban bagi BUS/ UUS dan KJKS/UJKS-Koperasi untuk selalu melakukan transparansi berkaitan dengan penyampaikan informasi Linkage Program sejauh tidak melanggarketentuanyangberlaku. 3).Ketentuan bahwa satu jaminan hanya untuk dijaminkan kepada satu sohibul maal mitra pembiayaan (BUS/UUS); 4).Larangan untuk membebani debitur dengan marjin/ nisbah bagi hasil yang lebih tinggi dari harga pasar untuk sektor usaha UMK yang dibiayai, khususnya dalam pelaksanaan dengan pola joint financing dan channeling. 5).Kewajiban bagi KJKS/UJKS-Koperasi yang mengikuti Linkage Program harus memelihara predikat penilaian kesehatan.

\section{Analisis Pengaturan Linkage Program dalam Pemberdayaan Usaha Mikro Kecil}

Dalam UU Nomor 20 Tahun 2008 tentang UMKM, terdapat beberapa pasal yang berkaitan dengan Linkage Program, antara lain adalah pasal-pasal yang berkaitan dengan pendanaan, misalnya pasal 7 dan 8 . Pada pasal 8, disebutkan bahwa dalam akses pendanaan bagi UKM dapat diperluas dengan mengakses kredit perbankan dan lembaga keuangan bukan bank; selain itu juga memberikan kemudahan dalam memperoleh pendanaan secara cepat, tepat, murah, dan tidak diskriminatif dalam pelayanan sesuai dengan ketentuan peraturan perundangundangan; dan membantu para pelaku Usaha Mikro dan Usaha Kecil untuk mendapatkan pembiayaan dan jasa/produk keuangan lainnya yang disediakan oleh perbankan dan lembaga keuangan bukan bank, baik yang menggunakan sistem konvensional maupun sistem syariah dengan jaminan yang disediakan oleh Pemerintah.

Selain pasal 7 dan 8 di atas pada Bab VII tentang Pembiayaan dan Jaminan khususnya bagi UKM, dalam pasal 22 disebutkan bahwa dalam rangka meningkatkan sumber pembiayaan Usaha Mikro dan Usaha Kecil, Pemerintah melakukan berbagai upaya, baik melalui kerjasama dengan lembaga perbankan maupun non perbankan, dalam memperoleh sumber pembiayaan kredit. Selain dari bank maupun non bank, kerjasama juga dilakukan dengan koperasi simpan pinjam dan koperasi jasa keuangan konvensional dan syariah.

Pada bagian e pasal 22 disebutkan berkaitan dengan pembiayaan ini, bahwa pengembangan sumber pembiayaan lain akan diatur sesuai dengan ketentuan peraturan perundang-undangan. Dimana dalam penjelasan dikatakan dalam rangka pelaksanaan kegiatan pembiayaan untuk 
Usaha Mikro berdasarkan Undang-Undang ini dapat dikembangkan khusus sebuah lembaga keuangan untuk Usaha Mikro sesuai dengan peraturan perundang-undangan.

Selanjutnya tertuang dalam pasal 23, yang intinya untuk meningkatkan akses bagi UKM, maka pemerintah daerah juga memiliki peran, antara lain dengan memperluas jaringan lembaga keuangan bukan bank; maupun lembaga penjamin kredit dan kemudahan dan fasilitas dalam memenuhi persyaratan untuk memperoleh pembiayaan.

Selain dari UU UMKM, dalam UU Bank Indonesia tampak komitmen Bank Indonesia sebagai bank sentral di Indonesia berdasar Undang-undang tentang Bank Indonesia No. 23 Tahun 1999 dalam membantu usaha UMKM yang sifatnya tidak langsung dan lebih terfokus kepada bantuan teknis serta pengembangan kelembagaan yang menunjang UMKM. Upaya-upaya Bank Indonesia tersebut dilakukan melalui (1).Kebijakan kredit perbankan, (2).Pengembangan kelembagaan, (3).Pemberian bantuan teknis dan (4) Kerjasama Bank IndonesiaPemerintah dan lembaga terkait lainnya.

Berkaitan dengan kebijakan kredit perbankan, beberapa peraturan dan kebijakan telah diterbitkan oleh Bank Indonesia, berkaitan dengan UMK yaitu: 1).Peraturan Bank Indonesia (PBI) No. 3/2/PBI/2001 tentang "Pemberian Kredit Usaha Kecil", yang menyempurnakan ketentuan tentang Kredit Usaha Kecil (KUK). PBI ini tidak mewajibkan bank untuk menyalurkan KUK, tetapi menganjurkan agar penyaluran KUK sesuai dengan business plan-nya; 2).Peraturan Bank Indonesia PBI No. 7/2/PBI/2005 tentang Penilaian Kualitas Aktiva Bank Umum yang mengatur bahwa penetapan kualitas kredit dan penyediaan dana lain sampai dengan Rp500 juta (usaha mikro dan kecil) hanya didasarkan atas ketepatan pembayaran pokok dan atau bunga.

Dalam rangka pengembangan kelembagaan yang menunjang UKM, maka salah satunya adalah dengan melakukan kerjasama antar Lembaga Keuangan (linkage program) sebagaimana telah dibahas sebelumnya.

\section{Pengaturan Linkage Program berdasar Kaidah Substantif dan Kaidah Administratif}

Dari uraian yang telah disebutkan pada sub-bab sebelumnya, maka ada 2 aturan yang secara langsung membahas tentang linkage program, pertama adalah Generic Linkage Program Bank Indonesia dalam rangka API, dan berikutnya adalah Peraturan Menteri Negara Koperasi dan Usaha Kecil dan Menengah Republik Indonesia. Nomor: 03/ Per/M.KUKM/III/2009 Tentang: Pedoman Umum Linkage Program Antara Bank Umum Dengan Koperasi.

Apabila dikelompokkan, maka dapat dibagi menjadi 2 (dua) kategori yaitu, pengaturan subtantif dan pengaturan administrative, sebagai berikut.

Kaidah substantif atau materiel yang dimaksud adalah segala ketentuan hukum yang dibuat oleh aparat legislatif, yudikatif 
ekonomi nasional serta akurasi kebijakan politik pemerintah, sehingga tidak dapat disimpangi atau diabaikan oleh para pelaku ekonomi. Tujuannya adalah agar pelaksanaan dalamaktivitas ekonomiberjalan padakeadilan dan kepastian hukum. Contoh dalam kaidah linkage program adalah tentang apabila para pihak telah sepakat memilih dan menentukan executing sebagai pola linkage programnya, maka akad/ perjanjiannya adalah dengan mudharabah, dimana ketentuan mudharabah berlaku mengikat sebagaimana ditentukan dalam peraturan perundang-undangan.

Kaidah administrasi atau prosedural adalah ketentuan hukum administrasi negara mengenai aspek-aspek prosedural dari aktivitas dan transaksi ekonomi, yang dibuat oleh aparatur administrasi negara atau pihak eksekutif serta memiliki kekuatan hukum memaksa agar ketentuan dan persyaratan yang diatur dalam ketentuan tersebut dipatuhi oleh publik. Pada umumnya berbentuk PP, Keppres, Inpres, SK Mentri. Pada Peraturan Menteri Negara Koperasi dan Usaha Kecil dan Menengah Republik Indonesia. Nomor: 03/Per/M.KUKM/III/2009 Tentang: Pedoman Umum Linkage Program Antara Bank Umum Dengan Koperasi, tampak sekali kaidah administrasi tatau proseduralnya, misalnya pembatasan penyaluran, pelaporan dan sebagainya. Sanksi dalam kaidah administratif juga bersifat tegas, mulai pembatalan, pencabutan, penutupan usaha dll. Hanya saja dalam Peraturan Menteri Negara Koperasi dan Usaha Kecil dan Menengah Republik Indonesia. Nomor: 03/Per/M.KUKM/III/2009
Tentang: Pedoman Umum Linkage Program Antara Bank Umum Dengan Koperasi ini, belum tampak adanya sanksi yang tegas apabila tidak dipatuhinya ketentuan administratif atau prosedural tersebut. Beberapa ketentuan yang dapat ditingkatkan menjadi sanksi adalah kode etik dalam linkage program.

Pengaturan berisi kaidah/norma substantif adalah dalam rangka menjamin adanya keadilan, kepastian dan kemanfaatan, maka kaidah administratif atau prosedural berkaitan dengan menjamin kepastian hukum.

\section{Simpulan}

Terdapat beberapa aturan yang mengatur Linkage Program bagi Lembaga Keuangan Syariah dalam rangka pemberdayaan Usaha Mikro Kecil Menengah di Indonesia dan pengaturannya tersebar dalam beberapa jenis aturan. Kebijakan pengaturan Linkage Program dapat ditemukan sejak dicanangkannya Arsitektur Perbankan Indonesia, dalam cetak biru khususnya dalam Generic Linkage Program Bank Indonesia (Cetak biru Perbankan Indonesia ini diibaratkan sebagai "GBHN" bagi perbankan di Indonesia). Selain itu, diatur juga khusus untuk koperasi dalam Peraturan Menteri Negara Koperasi dan Usaha Kecil dan Menengah Republik Indonesia. Nomor: 03/Per/M.KUKM/III/2009 Tentang: Pedoman Umum Linkage Program Antara Bank Umum Dengan Koperasi

Secara garis besar, kebijakan berkaitan dengan Linkage Program untuk Lembaga Keuangan Syariah dapat dikelompokkan 
menjadi 2, yaitu yang berkaitan dengan substanstif/materiel, dan administratif/ prosedural. Kaidah yang besifat materiel, lebih mengatur hubungan para pihak, perjanjian yang mengikat, dll, dan lebih detilnya tunduk pada peraturan perundang-undangan lain yang telah ada, misalnya UU No. 21 tahun 2008 tentang perbankan Syariah, atauPBI No. 7/46/PBI/2005 tentang Akad penghimpunan dan penyaluran Dana Bagi Bank yang Melaksanakan Kegiatan Usaha Berdasarkan Prinsip Syariah, juga dalam PBI No.: 9/19/ PBI/2007 tentang Pelaksanaan Prinsip Syariah dalam Kegiatan penghimpunan dana dan penyaluran Dana Serta Pelayanan Jasa Bank Syariah. Adapun kaidah prosedural/ administratif, lebih berisi persyaratanpersyaratan untuk melaksanakan linkage program, misalnya syarat badan hukum, plafond pembiayaan, tingkat kesehatan dll.
Dengan tersebarnya dalam berbagai aturan tersebut diperlukan sebuah peraturan khusus tentang linkage program, yang dapat dalam wadah POJK (peraturan Otoriras Jasa Keuangan) mengingat lembaga keuangan terkait berada di bawah pengawasan OJK. Pentingnya kaidah subtantif untuk linkage program adalah dalam rangka pemberdayaan UKM yang membutuhkan peraturan yang lengkap. Beberapa kekurangan dalam pengaturan linkage program mendorong pelaku membuat perjanjian yang tidak sesuai dengan ketentuan syariah, maupun pedoman dalam linkage program. Misalnya adalah adanya multi-akad dalam praktik. Demikian pula dalam kaidah administratif/prosedural, diperlukan adalanya pengaturan yang tegas, bukan sekedar kode etik bagi pelaku linkage program.

\section{DAFTAR PUSTAKA}

Bank Indonesia, 2005, Booklet perbankan Indonesia.

Bank Indonesia, 2009, Booklet Perbankan Syariah.

Bank Indonesia, tanpa tahun, Generik Model

Linkage Program (Antara BUS/UUS dengan BPRS).

Dahlan Siamat, 1999, Manajemen Lembaga

Keuangan, FEUI, .

Muhammad, 2009, Lembaga Keuangan Syariah, Pergulatan Melawan Kemiskinan dan penetrasi Ekonomi

Global, Graha Ilmu, Yogjakarta.
Sukarmi dkk, 2007, Analisis Potensi Bisnis UKM Jawa Timur dalam Rangka Menghadapi Integrasi Pasar Asean, Bank Indonesia dan Lembaga Riset Perbankan Jawa Timur (LRPD).

S. Soekanto \& Sri Mamudji, 2003, Penelitian Hukum Normatif; Suatu Tinjauan Singkat, PT. Raja Grafindo Persada, Jakarta.

Sihabuddin, dkk, 2006, Evaluasi Peraturan Perbankan yang Menghambat Pembiayaan Usaha Kecil di Jawa 
Timur, Bank Indonesia dan Lembaga

Riset Perbankan Jawa Timur (LRPD).

Siti Hamidah, 2013, Kajian Yuridis terhadap Penggabungan 2 (dua) Akad pada Perjanjian Mudharabah wal Murabahah.

Siti Maesaroh, Efektivitas Linkage Program Bank Syariah Mandiri dalam Penguatan Pembiayaan Lembaga Keuangan Mikro, Skripsi, Fakultas Syariah dan Hukum, Universitas Islam Negeri Syarif Hidayatullah, Jakarta, 2011.

Tulus TH Tambunan, 2009, UMKM di Indonesia, Ghalia Indonesia, .

\section{Peraturan Perundang-undangan}

UU Nomor 7 Tahun 1992 tentang Perbankan.

UU Nomor 10 Tahun 1998 tentang Perubahan

UU Nomor 7 Tahun 1992 tentang Perbankan.

UU Nomor 20 tahun 2008 tentang Usaha Mikro Kecil Menengah.

UU Nomor 21 Tahun 2008 tentang Perbankan Syariah.

UU Nomor 1 Tahun 2013 tentang Lembaga
Keuangan Mikro.

PBI Nomor: 9/19/PBI/2007 tentang Pelaksanaan Prinsip Syariah dalam Kegiatan penghimpunan dana dan penyaluran Dana Serta Pelayanan Jasa bank Syariah.

Peraturan Menteri Negara Koperasi dan Usaha Kecil dan Menengah Republik Indonesia. Nomor: 03/Per/M.KUKM/ III/2009 tentang Pedoman Umum Linkage Program Antara Bank Umum Dengan Koperasi.

\section{Naskah Internet}

Ekonomi Islam, Menjadi Bank Syariah yang Ramah UMKM, http://ekisopini. blogspot.com/2009/08/menjadi-banksyariah-yang-ramah-umkm_4496.html.

\section{UMKM Sebagai Kekuatan Ekonomi di Propinsi Jawa Timur, http:// manajemen.ferano.narotama.ac.id/ download_berita/UMKM-1.pdf. \\ Genjot Sektor UMKM dengan Kredit Usaha Rakyat, Jurnal KUKM, Edisi November 2007.}




\title{
BADAN PENYELESAIAN SENGKETA KONSUMEN SEBAGAI PERWUJUDAN PERLINDUNGAN HAK KONSUMEN
}

\author{
Murni dan Sri Maharani MTVM \\ Universitas Trunojoyo Madura \\ Raya Telang PO Box 2, Bangkalan, Madura \\ Email:murni_msy@yahoo.co.id
}

\begin{abstract}
The background of this study is the absence of the Consumer Dispute Resolution Board (BPSK) in the region of Madura. This legal empirical study, in order to examine the legal aspects as well as to identify opportunities and obstacles to the establishment of BPSK. The results of this study put the structural problem as the main reason, unrealized funding that are being considered by the government. Important to be done is to provide a basis for the establishment of BPSK through regulation in each area and the government's commitment to provide the financial support in the budget.
\end{abstract}

Key words: alternative, model, dispute, consumer

\begin{abstract}
Abstrak
Penelitian ini dilatar belakangi belum adanya Badan Penyelesaian Sengketa Konsumen (BPSK) di wilayah Madura. Ini adalah penelitian hukum empiris, tujuannya untuk mengkaji aspek hukum dan mengetahui peluang juga kelemahan pendirian kelembagaan BPSK di wilayah Madura. Hasil dari penelitian ini menempatkan problem struktural menjadi alasan terdepan tidak terbentuknya BPSK di wilayah Madura, alasan pendanaan juga menjadi pertimbangan pemerintah daerah tidak merealisasikan lembaga ini. Penting untuk dilakukan adalah memberikan payung hukum bagi lahirnya kelembagaan BPSK melalui Peraturan Daerah di masing-masing Kabupaten dan komitmen pemerintah untuk memberikan dukungan financial dalam APBD.
\end{abstract}

Kata kunci: alternatif, model, sengketa, konsumen

\section{Latar Belakang}

Meningkatnya laju perekonomian Kabupaten Bangkalan, sebagai pintu gerbang di berbagai daerah, berdampak pada pertama menjadi barometerjuga menunjukkan peningkatan konsumsi masyarakat terhadap adanya perkembangan konsumsi masyarakat berbagai macam barang maupun jasa, Bangkalan serta kota-kota di Pulau Madura tidak terkecuali wilayah Madura yang kini lainnya mengikuti kota besar Surabaya. Akses telah terhubung oleh Jembatan Suramadu. Jembatan Suramadu telah mempermudah Pasca operasionalisasi jembatan Suramadu, pergerakan barang menuju Pulau Madura. 
Produk kecantikan dilengkapi dengan rumah cantik/klinik estetika, produk makanan dan minuman, jasa KBIH, usaha perumahan, bahkanproduk-produkelektronikyangcanggih serta automotif telah berkembang sangat pesat demikian pula produk khas Madura oleholeh khas Madura, wisata kuliner, batik khas Madura telah beredar di Surabaya,. Namun, berhubung pengetahuan konsumen terhadap rangkaian proses produksi maupun realisasi pelayanan jasa sangat rendah menyebabkan konsumen rentan terhadap kecurangankecurangan yang mungkin dilakukan oleh pelaku usaha. Banyak sekali keluhan-keluhan pada masyarakat selaku konsumen di Madura yang tidak tahu bagaimana mempertahankan haknya ketika mereka berhadapan dengan pelaku usaha nakal, seperti ikan berformalin, pengembang perumahan nakal di Bangkalan, korban penggunaan kosmetik $^{1}$ serta penyedia jasa ibadah haji KBIH yang ada di Pamekasan. ${ }^{2}$

Berdasarkan penelusuran tim peneliti terkait kasus konsumen, di empat kabupaten di wilayah Madura mempunyai karakter yang sama. Kasus-kasus yang bersumber dari pelaku usaha swasta atau produsen swasta yaitu korban konsumen perumahan/property dengan modus rumah tidak sesuai spesifikasi dan tidak adanya fasilitas umum, produk makanan minuman kadaluarsa, pelayanan wisata religi atau umroh tidak sesuai promo dan ditimbunnya gas/LPG oleh distributor. ${ }^{3}$

Kepentingan pelaku usaha dan kepentingan konsumen yang saling berhadapan menuntut pemerintah untuk menyediakan sarana hukum bagi masyarakat dalam menyelesaikan sengketa yang terjadi antara dua pihak yaitu konsumen dan produsen, melalui dua mekanisme yaitu melalui jalur litigasi (formal peradilan) dan jalur non litigasi melalui Badan Penyelesaian Sengketa Konsumen (BPSK). Mekanisme di luar pengadilan rupanya lebih dipilih karena bersifat cepat, sederhana dan jauh dari komersialisasi jabatan layaknya sistem formal karena strukturnya tidak hanya melibatkan masyarakat sebagai end user atau konsumen akhir, tetapi juga terdapat pemerintah dan pelaku usaha.

Sebagai amanat dari tujuan perekonomian nasional yang telah ditetapkan dalam UUD 1945, yakni untuk mewujudkan kesejahteraan kepada masyarakat inilah Badan Penyelesaian Sengketa Konsumen diberikan peran dengan kewenangan luas sebagai pengawas dalam sistem perekonomian yang sehat dan bertanggungjawab, terutama sebagai pilar dalam perlindungan hukum terhadap konsumen melalui Undang-Undang Nomor 8 Tahun 1999 Tentang Perlindungan Konsumen. Payung hukum dimaksudkan untuk menciptakan iklim usaha yang sehat dalam rangka penyediaan barang dan atau jasa

1 Keterangan Bapak Jimhur Saros, YLKI Madura dan Laporan masyarakat pada UPKH, Fakultas Hukum Universitas Trunojoyo Madura, 2012-2013.

2 Koran Madura, Kemenag Belum Mampu Mendeteksi, http://www.koranmadura.com/kemenag-belummampu-mendeteksi/, diakses 9 Maret 2013 pukul 20.00 WIB.

3 Hasil penelusuran tim peneliti terkait karakteristik kasus konsumen di wilayah Madura periode Mei-Juli 2013. 
yang berkualitas.

Namun untuk mewujudkan amanat undang-undnag dalam membentuk BPSK oleh setiap daerah Kabupaten ternyata tidak mudah masih terdapat beberapa kendala, baik kendala dari sisi kelembagaannya, teknis maupun struktural. Sehingga ketiadaan BPSK dan minimnya pengetahuan hak-hak konsumen oleh masyarakat di Madura menyebabkan banyaknya keluhan-keluhan konsumen tersebut hanya menjadi cerita belaka, stigma negatif bila berhadapan dengan hukum formal dan rendahnya kepercayaan terhadap sistem peradilan akhirnya menyurutkan langkah mereka untuk mempertahankan hak-haknya sebagai konsumen.

Kesulitan akan semakin menjadi tatkala ada keluhan dari konsumen-konsumen sebagai turis domestik di Madura yang membeli produk lokal maupun produk luar ketika berada di Madura, mereka tidak tahu harus menyampaikan kemana. Dengan demikian keberadaan BPSK dapat menjadi solusi bagi konsumen untuk memperjuangkan hak-haknya serta dapat menyurutkan niat pelaku usaha lokal yang nakal dan secara tidak langsung akan meningkatkan citra Madura di hadapan masyarakat maupun para pendatang di Pulau Madura.

Tujuan pembangunan nasional Indonesia adalah mewujudkan masyarakat adil dan makmur yang merata dalam era demokrasi ekonomi berdasarkan Pancasila dan UndangUndang Dasar Negara Republik Indonesia Tahun 1945. Pembangunan perekonomian nasional pada era globalisasi harus dapat mendukung tumbuhnya dunia usaha sehingga mampu menghasilkan bermacam-macam barang dan/atau jasa yang dapat meningkatkan kesejahteraan masyarakat banyak, sekaligus mendapatkan kepastian atas barang dan atau jasa yang diperoleh dari perdagangan tanpa mengakibatkan kerugian kepada konsumen.

Permasalahan yang timbul dalam situasi ini adalah:

"Lemahnya perlindungan hukum terhadap konsumen di Madura yang ingin mempertahankanhak-haknya",olehkarenanya untuk mendekatkan pada tercapainya keadilan konsumen untuk mendapatkan barang yang murah dan berkualitas, maka sebagai pemenuhan hak konsumen tersebut dapat dilakukan melalui pendirian BPSK disetiap Kabupaten di Madura. Untuk itu dalam penelitian ini menjawab beberapa hal yang menjadi dasar bagi analisis pendirian BPSK di wilayah Madura, antara lain:

1. Dalam rangka mewujudkan hak-hak konsumen di Madura, Bagaimanakah kebijakan Pemerintah Daerah terkait pendirian BPSK konsumen di wilayah Madura pasca disahkan UndangUndang Nomor 8 Tahun 1999 tentang Perlindungan Konsumen?

2. Bagaimanakah model pengaturan hukum bagi pembentukan BPSK di wilayah Madura?

Penelitian ini merupakan penelitian hukum empiris atau penelitian hukum non doktrinal disebut juga sebagai penelitian 
hukum sosiologis (sosio legal research) yang dalam penelitian ini menitikberatkan terhadap bekerjanya hukum dimasyarakat. ${ }^{4}$

Lokasi penelitian dilaksanakan pada empat Kabupaten di Pulau Madura yaitu: Kabupaten Bangkalan, Kabupaten Sampang, Kabupaten Pamekasa, Kabupaten Sumenep, serta kegiatan analisis di laboratorium Hukum Universitas Trunojoyo.

Data primer diperoleh dengan mengunakan Teknik wawancara mendalam melalui FGD (Focus Group Discussion) dengan berbagai pihak, instansi terkait serta masyarakat.. Informan kunci yang menjadi sumber data primer dalam penelitian ini adalah yang berkaitan langsung sebagai pihak-pihak yang terlibat dalam rencana pelembagaan BPSK di Madura, antara lain: Masyarakat/Konsumen, Pelaku Usaha, dan Unsur Pemerintahan Daerah terkait penelitian. Sumber data sekunder diperoleh dari kantorkantor pemerintahan maupun pelaku usaha dan juga kantor-kantor penegak hukum bila diperlukan.

Data kualitatif yang diperoleh selama penelitian tersebut, kemudian ditambah dengan pernyataan-pernyataan para informan (interpretasi emik) dijadikan sebagai dasar untuk menyusun deskripsi menurut persepsi peneliti (interpretasi etik) yang menyangkut berbagai hal guna mendukung proses konstruksi yuridis BPSK di Madura.

\section{Pembahasan}

A. Kebijakan Pemerintah Daerah Terkait Pembentukan BPSK di Madura Pasca Undang-undang Nomor 8 Tahun 1999 Tentang Perlindungan Konsumen

Sejak di undangkan UUPK pada tahun 1999 dan ini kini telah berusia 15 (lima belas) tahun, kenyatannya di Madura belum terbentuk lembaga yang mengarah pada perlindungan konsumen yang melibatkan campur tangan pemerintah.

Usaha-usaha yang dilakukan oleh pemerintah di empat Kabupaten di Madura hampir semuanya sama yaitu masih bersifat lintas sektoral. Penelusuran kami pada Dinas Perindustrian dan Perdagangan setiap tahun mereka mempunyai program sosialisasi dengan tema "Perlindungan Konsumen".

Di Kabupaten Sumenep Disperindag memprogramkan setiap minggu melakukan operasi pasar terpadu bersama dinas kesehatan. Disperindag menkhususkan lebih pada otoritas tata niaga pasar, sedangkan dinkes terkait ijin layak edar. Beberapa tahun ini disperindag sebagai SKPD yang mempunyai sie khusus perlindungan konsumen telah mengusulkan berdirinya BPSK di wilayahnya, akan tetapi hal ini tidak pernah menjadi skala prioritas program legislasi daerah, dengan alasan pendanaan yang bersumber dari APBD. ${ }^{5}$

4 Bambang Sunggono, Pengantar Metode Penelitian Hukum, Rajawali, Jakarta, 2006, hlm. 34.

5 Wawancara dengan Bapak Didik Prayitno, Bidang Promosi dan Perlindungan Konsumen Disperindag PemKab. Sumenep, 1 Agustus 2013. 
Perhatian terhadap perlindungan konsumen di Kabupaten Pamekasan sebenarnya lebih berkembang di banding Kabupaten lain di Madura, tercatat ada 3 (tiga) LPKSM (Lembaga Perlindungan Konsumen Swadaya Masyarakat) yaitu PKPU, LPPKI, dan LPKNI. ${ }^{6}$ Dalam Peratutan Pemerintah (PP) Nomor 59 Tahun 2001 (59/2001) Tentang Lembaga perlindungan Konsumen Swadaya Masyarakat pada pasal 1 ayat 3 di tentukan bahwa Lembaga Perlindungan Konsumen Swadaya Masyarakat yang selanjutnya disebut LPKSM adalah Lembaga Non Pemerintah yang terdaftar dan diakui oleh Pemerintah yang mempunyai kegiatan menangani perlindungan konsumen. Sedangkan di Pasal 3 dalam PP ini mengatur tugas LPKSM yaitu meliputi kegiatan:

a. menyebarkan informasi dalam rangka meningkatkan kesadaran atas hak dan kewajiban serta kehati-hatian konsumen, dalam mengkonsumsi barang dan/atau jasa;

b. memberikan nasihat kepada konsumen yang memerlukan;

c. melakukan kerja sama dengan instansi terkait dalam upaya mewujudkan perlindungan konsumen;

d. membantu konsumen dalam memperjuangkan haknya, termasuk menerima keluhan atau pengaduan konsumen; e. melakukan pengawasan bersama pemerintah dan masyarakat terhadap pelaksanaan perlindungankonsumen.

Setidaknya dengan adanya tiga LPKSM di Kabupaten Pamekasan telah memberikan rasa nyaman sebagai konsumen untuk menikmati berbagai kebutuhan fisik masyarakat. Dengan memperhatikan tugas-tugas yang di emban oleh LPKSM ini. Setiap ada kegiatan terkait operasi pasar yang bertujuan untuk pengawasan peredaran makanan minuman di Kabupaten Pamekasan ketiga LPKSM ini di libatkan, hal ini di kuatkan dengan Surat Keputusan (SK) Bupati Pamekasan nomor 188/141.131/2013 tentang Pembentukan Tim Koordinasi Pembinaan dan Pengawasan Peredaran Mamin Konsumsi Masyarakat. Meskipun hanya berkisar pada pengawasan mamin, paling tidak sudah ada perhatian oleh pemerintah terhadap konsumen.

Selebihnya di Kabupaten lain masih pada standart sosialisasi baik secara langsung melalui penyuluhan, maupun penerbitan brosur "menjadi konsumen cerdas" dan operasi pasar yang dilakukan bekerjasama dengan Dinas Kesehatan.

Penyebab lain tidak optimalnya program operasi pasar di karenakan minimnya PPNS (Penyidik Pegawai Negeri Sipil) yang di punyai oleh Disperindag menyebabkan tidak berjalannya penegakan hukum di bidang perlindungan konsumen ini, karena hanya

6 Wawancara dengan Bapak Hendradi Kabid, Perlindungan Konsumen dan Bapak Imam Hidajad PPNS Disperindag Kabupaten Pamekasan, 25 Juli 2013. 
PPNS yang berwenang mengambil tindakan akibat pelanggaran-pelanggaran yang dilakukan oleh pelaku usaha. Selain itu alasan kemanusiaan bagi pelaku usaha kecil apabila mereka di tindak.

Program-program pemerintah tersebut senyatanya menjadi tidak maksimal karena hanya untuk melakukan kewajiban kerja dan bersifat preventif saja, sedangkan terbentuknya BPSK tidak menjadi prioritas bagi pemerintahan di daerah padahal ini diamanatkan oleh pasal 49 UUPK. Alasan yang dikemukaan tidak ada payung hukum yang merupakan produk legislasi di daerah bagi pendiriannya dan keberadaannya menjadi beban bagi APBD masing-masing daerah.

\section{B. Rumusan Model Pengaturan Hukum BPSK sebagai Perwujudan Perlindungan terhadap Konsumen di Wilayah Madura}

Perlindungan hukum adalah suatu perlindungan yang diberikan kepada subyek hukum ke dalam bentuk perangkat baik yang bersifat preventif maupun yang bersifat represif, baik yang lisan maupun yang tertulis. Dengan kata lain dapat dikatakan bahwa perlindungan hukum sebagai suatu gambaran tersendiri dari fungsi hukum itu sendiri, yang memiliki konsep bahwa hukum memberikan suatu keadilan, ketertiban, kepastian, kemanfaatan dan kedamaian. Pengertian di atas mengundang beberapa ahli untuk mengungkapkan pendapatnya mengenai pengertian dari perlindungan hukum diantaranya: a. Menurut Satjipto Raharjo mendefinisikan Perlindungan Hukum adalah memberikan pengayoman kepada hak asasi manusia yang dirugikan orang lain dan perlindungan tersebut diberikan kepada masyarakat agar mereka dapat menikmati semua hak-hak yang diberikan oleh hukum.

b. Menurut Philipus M. Hadjon membagi perlindungan hukum kedalam dua bagian yaitu

c. Perlindungan hukum represif yaitu dengan cara menerapkan sanksi terhadap pelaku agar dapat memulihkan hukum pada keadaan sebenarnya. Perlindungan jenis ini biasanya dilakukan di pengadilan

- Perlindungan hukum Preventif yaitu perlindungan hukum yang bertujuan untuk mencegah terjadinya sengketa Perlindungan hukum jenis ini misalnya sebelum pemerintah menetapkan suatu aturan/keputusan rakyat dapat mengajukan keberatan atau diminta pendapatnya mengenai keputusan tersebut.

- Menurut CST Kansil Perlindungan Hukum adalah berbagai upaya hukum yang harus diberikan oleh aparat penegak hukum untuk memberikan rasa aman, baik secara pikiran maupun fisik dari gangguan dan berbagai ancaman dari pihak manapun.

d. Menurut Muktie, A. Fadjar Perlindungan Hukum adalah penyempitan arti dari perlindungan, dalam hal ini hanya 
perlindungan oleh hukum saja. Perlindungan yang diberikan oleh hukum, terkait pula dengan adanya hak dan kewajiban, dalam hal ini yang dimiliki oleh manusia sebagai subyek hukum dalam interaksinya dengan sesama manusia serta lingkungannya. Sebagai subyek hukum manusia memiliki hak dan kewajiban untuk melakukan suatu tindakan hukum. ${ }^{7}$

Pengaturan tentang perlindungan konsumen di Indonesia telah dimulai sejak zaman Hindia Belanda, kendatipun sebagian besar peraturan-peraturan tersebut pada saat ini sudah tidak berlaku lagi. Beberapa peraturan yang berkaitan dengan perlindungan konsumen pada saat itu antara lain:

1. Reglement Industriele Eigendom, $\mathrm{S}$, 1912-545, jo. S. 1913 No.

2. Hinder Ordonnantie (Ordonansi Gangguan), S. 1926-226 jo. S. 1927 449, jo. S. 1940-14 dan 450.

\section{Loodwit Ordonnantie (Ordonansi}

Timbal Karbonat), S. 1931 No. 28.

4. Tin Ordonnantie (Ordonansi Timah Putih), S. 1931-509.

5. Vuurwerk Ordonnantie (Ordonansi Petasan), S. 1932-143.

6. Verpakkings Ordonnantie (Ordonansi Kemasan), S. 1935 No. 161.

7. Ordonnantie $O p$ de Slacth Belasting (Ordonansi Pajak Sembelih), S. 1936671.
8. Sterkwerkannde Geneesmiddelen Ordonnantie (Ordonansi Obat Keras), S. 1937-641.

9. Bedrijfsrelementerings Ordonnantie (Ordonansi Penyaluran Perusahaan), S. $1938-86 .^{8}$

Pada sisi lain, dalam beberapa kitab undang-undang juga terdapat beberapa ketentuan yang dapat digunakan untuk melindungi konsumen, yaitu:

1. KUH Perdata: Bagian 2, Bab V, Buku II mengatur tentang kewajiban penjual dalam perjanjian jual beli.

2. KUHD: tentang pihak ketiga yang harus dilindungi, tentang perlindungan penumpang/barang muatan pada hukum maritim, ketentuan mengenai perantara, asuransi, surat berharga, kepalitian, dan sebagainya.

3. KUH Pidana: tentang pemalsuan, penipuan, pemalsuan merk, persaingan curang, dan sebagainya. ${ }^{9}$

Peranan konsumen, produsen dan pemerintah dalam mewujudkan perlindungan konsumen, merekomendasikan Dalam upaya mewujudkan perlindungan konsumen sangat tergantung pada peran dan sikap kritis konsumen sebagai pembeli barang atau jasa. Namun, faktor lain yang juga tidak kalah penting adalah sikap produsen sebagai pihak pemroduksi barang atau jasa yang seharusnya berorientasi pada kepuasan konsumen dan

7 Tesis Hukum, Pengertian, Perlindungan Hukum Menuru Para Ahli, http://tesishukum.com/pengertianperlindungan-hukum-menurut-para-ahli/, diakses 28 Agustus 2014 pukul 19.00 WIB.

8 Zulham, Hukum Perlindungan Konsumen, Kencana Prenada Media Group, Jakarta, 2013, hlm. 32.

9 Ibid., hlm. 33. 
barang yang diproduksi memenuhi standar mutu yang telah ditetapkan. Pemerintah dalam hal ini berkaitan dengan pembuatan UndangUndang Perlindungan Konsumen, dan Departemen Perdagangan harus mengawasi produk atau jasa yang beredar di dalam perdagangan dalam negeri, yang diekspor maupun yang diimpor, serta peran dari aktivitas organisasi konsumen itu sendiri. ${ }^{10}$

Dirumuskan Tujuan Negara RI dalam Pembukaan UUD Negara RI Tahun 1945, Alinea ke IV:

"Kemudian dari pada itu untuk membentuk suatu Pemerintah Negara Indonesia yang melindungi segenap bangsa Indonesia dan seluruh tumpah darah Indonesia dan untuk memajukan kesejahteraan umum, mencerdaskan kehidupan bangsa, dan ikut melaksanakan ketertiban dunia yang berdasarkan kemerdekaan, perdamaian abadi dan keadilan sosial".

Keadilan dapat dimaknai sebagai legalitas. Adalah adil jika suatu aturan diterapkan pada semua kasus di mana menurut isinya memang aturan tersebut harus diaplikasikan. Adalah tidak adil jika suatu aturan diterapkan pada satu kasus tetapi tidak pada kasus lain yang sama. Keadilan dalam arti legalitas adalah suatu kualitas yang tidak berhubungan dengan isi tataran aturan positif, tetapi dengan pelaksanaannya. Menurut legalitas, pernyataan bahwa tindakan individu adil atau tidak adli berarti legal atau illegal, yaitu tindakan tersebut sesuai atau tidak dengan norma hukum yang valid untuk menilai sebagai bagian dari tata hukum positif. ${ }^{11}$

Perlindungan konsumen merupakan masalah nasional sebab pada dasarnya semua orang adalah konsumen, melindungi konsumen adalah melindungi semua orang. Persoalan perlindungan hukum kepada konsumen adalah masalah hukum nasional, oleh karena itu perlindungan terhadap konsumen bertujuan untuk menjamin keselamatan, kemananan, dan kesehatan warga negara, sebagai tujuan negara.

Pasal 28 D butir (1) UUD RI Tahun 1945 mengatur: setiap orang berhak atas pengakuan, jaminan, perlindungan dan kepastian hukum yang adil serta perlakuan yang sama dihadapan hukum". Pasal 28 I, butir (4): "Perlindungan, pemajuan, penegakan dan pemenuhan hak asasi manusia adalah tanggung jawab Negara terutama pemerintah".

Perlindungan konsumen menjadi penting karena selama ini kedudukan konsumen pada umumnya lemah di hadapan pelaku usaha, merupakan kewajiban Negara melindungi hak-hak konsumen, sebagai bentuk pengakuan terhadap Hak Asasi Manusia, oleh karenanya akan dirumuskan berdirinya BPSK di wilayah Madura, sebagaimana analisa yuridis di bawah ini.

10 Euis Soliha, Peranan Konsumen, Produsen dan Pemerintah dalam Mewujudkan Perlindungan Konsumen, Jurnal Gema Stikubank, Volume 31 No. 5, Sekolah Tinggi Ilmu Ekonomi Stikubank, Semarang, 1999, hlm. 93-105.

11 Jimly Asshiddiqie \& M.Ali Safa'at, Teori Hans Kelsen Tentang Hukum, Konstitusi Press, Jakarta, 2012, hlm. 21. 
Undang-Undang Nomor 8 Tahun 1999 tentang Perlindungan Konsumen merupakan produk hukum yang bersifat peraturan payung" mengatur penyelesaian sengketa konsumen. Penyelesaian sengketa konsumen dilakukan dengan 2 jalan Penyelesaian Sengketa Konsumen hanya dari aspek perdata atau pertanggungjawaban perdata dengan cara melalui mediasi atau konsiliasi atau arbitrasi. Pada dasarnya upaya penyelesaian sengketa konsumen bersifat sukarela artinya pelaku usaha yang menolak atau tidak memberikan tanggapan atau bahkan tidak memenuhi gantirugi maka dapat memberikan kesempatan kepada konsumen untuk mengajukan gugatan kepada Badan Penyelesaian Sengketa Konsumen atau mengajukan ke pengadilan umum. Tuntutan ganti-rugi dan atau tuntutan pidana dapat dilakukan oleh konsumen yang dirugikan atau ahli warisnya dilakukan melalui gugatan perwakilan atau oleh lembaga swadaya masyarakat/hak gugat LSM. ${ }^{12}$

Dengan dasar filosofi bahwa konsumen tidak mengetahui secara pasti rangkaian proses produksi suatu produk yang menyebabkan konsumen rentan terhadap berbagai bentuk kecurangan yang mungkin dilakukan oleh pelaku usaha, menjadi acuan perlu adanya perlindungan pada konsumen. Perlindungan konsumen yang dimaksud secara khusus diatur dalam UU No. 8 Tahun 1999 tentang Perlindungan Konsumen, dimana dalam undang-undang tersebut ditentukan juga mengenai lembaga yang bertugas menyelesaikan sengketa konsumen yang timbul dari suatu transaksi konsumen. Salah satu lembaga yang dimaksud adalah Badan Penyelesaian Sengketa Konsumen (BPSK). BPSK sebagai salah satu lembaga penyelesaian sengketa mempunyai karakteristik khusus karena mempunyai sifat multifungsi, selain sebagai adjudication juga sekaligus sebagai consultative function. Penyelesaian melalui lembaga ini merupakan alternatif yang dapat ditempuh konsumen secara sukarela untuk memperjuangkan pemenuhan hak konsumen selain melalui peradilan umum. ${ }^{13}$

Wawancara mendalam dengan narasumber dari instansi teknis terkait perlindungan konsumen di wilayah Madura dan hasil analisis yuridis dalam penelitian ini, dapat di tegaskan bahwa untuk menentukan model pengaturan hukum bagi pendirian BPSK di Madura ini ada dua pendapat hukum yang bisa dipertimbangkan:

1. Tidak bisa di bentuk BPSK, karena tidak ada Peraturan Daerah yang mengaturnya.

2. Membentuk BPSK berdasarkan amanat pasal 49 UUPK tanpa Peraturan Daerah. ${ }^{14}$

Kedua pendapat tersebut sama-sama bisa di terima alasan pendukungnya, dengan analisis yuridis sebagaimana berikut ini:

12 Ari Purwadi, Model Penyelesaian Sengketa Konsumen di Indonesia, Jurnal Yustika, Volume 4 No. 2 , Desember 2001, Media Hukum dan Keadilan, 2001, hlm. 254-273.

13 Bernadetta T.Wulandari, Badan Penyelesaian Sengketa Konsumen (BPSK) Sebagai Alternatif Upaya Penegakan Hak Konsumen di Indonesia, Gloria Juris, Volume 6 No. 2, Oktober 2006, hlm. 142-151.

14 Hasil FGD dengan instansi terkait perlindungan konsumen di wilayah Madura, sepanjang 2013-2014. 
1. Pertama, tidak adanya peraturan daerah menyebabkan tidak berdirinya BPSK di Madura.

Pihak instansi teknis terkait sebagai representative dari pemerintah menyatakan bahwa untuk bisa mendirikan BPSK di wilayah Madura harus terlebih dahulu di bentuk Peraturan Daerahnya.

Pendapat ini bisa kita cermati melalui argumentasi hukum berikut: bahwasanya sebuah "Badan" baru dalam sistem penyelenggaraan pemerintahan di daerah harus diperhatikan pengaturan yang mengacu pada Undang-undang nomor 23 tahun 2014 tentang Pemerintahan Daerah (Selanjutnya di singkat UU 23/2014), Pasal 208 mengatur:

(1) Kepala daerah dan DPRD dalam menyelenggarakan Urusan

Pemerintahan dibantu oleh Perangkat Daerah.

(2) Perangkat Daerah sebagaimana dimaksud pada ayat (1) diisi oleh pegawai aparatur sipil negara.

Selanjutnya dalam Pasal 209 Ayat (2) UU 23/2014, di atur bahwa: Perangkat Daerah kabupaten/kota terdiri atas:
a. sekretariat daerah;
b. sekretariat DPRD;
c. inspektorat;
d. dinas;
e. badan; dan
f. Kecamatan.

Pembentukan dan Susunan Perangkat Daerah dalam Pasal 212 UU 23/2014 juga diatur sebagai berikut:

(1) Pembentukan dan susunan Perangkat Daerah sebagaimana dimaksud dalam Pasal 209 ayat (1) dan ayat (2) ditetapkan dengan Perda.

(2) Perda sebagaimana dimaksud pada ayat (1) berlaku setelah mendapat persetujuan dari Menteri bagi Perangkat Daerah provinsi dan dari gubernur sebagai wakil Pemerintah Pusat bagi Perangkat Daerah kabupaten/kota.

(3) Persetujuan Menteri atau gubernur sebagai wakil Pemerintah Pusat sebagaimana dimaksud pada ayat (2) diberikan berdasarkan pemetaan Urusan Pemerintahan Wajib yang tidak berkaitan dengan Pelayanan Dasar dan Urusan Pemerintahan Pilihan sebagaimana dimaksud dalam Pasal 24.

(4) Kedudukan, susunan organisasi, perincian tugas dan fungsi, serta tata kerja Perangkat Daerah sebagaimana dimaksud pada ayat (1) ditetapkan dengan Perkada. Memperhatikan Pasal 209 jo. Pasal 212 UU 23/2014 maka "Badan" sebagai salah satu unsur perangkat daerah, pembentukannya harus di dahului dengan diaturnya pendirian "badan" dimaksud dengan sebuah "Peraturan Daerah". Dengan demikian BPSK di wilayah Madura sesuai amanat pasal49 UUPK barubisa di bentuk bila masing-masing pemerintahan daerah terlebih dahulu mengaturnya dalam sebuah "Peraturan Daerah" tentang BPSK.

2. Kedua, Membentuk BPSK berdasarkan 
amanat pasal 49 UUPK tanpa Perda.

Pendapat kedua terkait pengaturan hukum pendirian BPSK di Madura memberikan argumentasi terbalik dengan pendapat pertama tetapi dengan mengacu pada pasal-pasal yang sama dalam UndangUndang pemerintahan Daerah.

Kalau kita perhatikan dalam pasal 49 UUPK yang mengatur:

1. Pemerintah membentuk badan penyelesaian sengketa konsumen di Daerah Tingkat II untuk menyelesaikan sengketa konsumen di luar pengadilan.

2. Untuk dapat diangkat menjadi anggota badan penyelesaian sengketa konsumen, seseorang harus memenuhi syarat sebagai berikut:
a. warga negara Republik Indonesia;
b. berbadan sehat;
c. berkelakuan baik;
d. tidak pernah dihukum karena kejahatan;

e. memiliki pengetahuan dan pengalaman di bidang perlindungan konsumen;

f. berusia sekurang-kurangnya 30 (tiga puluh) tahun.

g. Anggota sebagaimana dimaksud pada ayat (2) terdiri atas unsur pemerintah, unsur konsumen, dan unsur pelaku usaha.

3. Anggota setiap unsur sebagaimana dimaksud pada ayat (3) berjumlah sedikit-dikitnya 3 (tiga) orang, dan sebanyak-banyaknya 5 (lima) orang.

4. Pengangkatan dan pemberhentian anggota badan penyelesaian sengketa konsumen ditetapkan oleh Menteri.

Pengaturan pada pasal 49 ayat 1 UUPK menyebutkan bahwa Pemerintah di tingkat kabupaten diwajibkan untuk membentuk BPSK. Sedangkan di ayat 3 disebutkan bahwa keanggotaan BPSK terdiri dari unsur pemerintah, unsur konsumen, dan unsur pelaku usaha.

Oleh karena unsur BPSK yang melibatkan pihak di luar pemerintah maka "Badan" di maksud bisa di kategorikan sebagai "Badan" yang bersifat Independen sehingga tidak wajib tunduk pada pengaturan pada UndangUndang Pemerintahan Daerah khususnya Pasal 209 jo Pasal 212 UU 23/2014, dengan demikian tanpa menunggu adanya Perda khusus mengenai BPSK seharusnya sudah bisa di bentuk "Badan" dimaksud dengan berlandaskan pada pengaturan:

- Undang-undang No. 8 tahun 1999 tentang Perlindungan Konsumen pasal 49

- Keputusan Menteri Perindustrian dan Perdagangan Nomor 301/MPP/ Kep/10/2001 tentang Pengangkatan dan Pemberhentian Anggota dan Sekretariat Badan Penyelesaian Sengketa Konsumen

- Surat Keputusan Menteri Perindustrian dan Perdagangan Nomor. 350/MPP/ Kep/12/2001 tentang Pelaksanaan Tugas dan Wewenang Badan Penyelesaian Sengketa Konsumen

- Keputusan Menteri Perindustraian dan Perdagangan Nomor 419/MPP/ Kep/4/2001 tentang Pembentukan Tim 
Penyeleksi Penetapan Anggota Badan

Penyelesaian Sengketa Konsumen

Kedua pendapat tersebut di atas memang sama-sama membawa konsekuensi yang berbeda, yang mana bila tidak memperdebatkan adanya peraturan daerah maka BPSK bisa segera di wujudkan di Madura. Akan tetapi bila menjadikan BPSK sebagai bagian dari "Badan" yang dimaksud dalam Undang-Undang Pemerintahan Daerah maka harus di atur terlebih dahulu dengan payung hukumnya yaitu Peraturan Daerah.

Menurut hemat kami agar tidak menimbulkan polemik di kemudian hari lebih baik di buatkan aturan khusus terkait pendirian BPSK di daerah ini, hal yang sangat sensitif dalam hal ini adalah terkait dengan penganggaran. Apalagi beberapa BPSK sebelumnya yang sudah berdiri pelaksanaannya dibebankan pada APBN dan APBD, dan pengesahan pendiriannya dengan payung hukum anatara lain dalam bentuk Keputusan Presiden Nomor 90 Tahun 2001 tentang Pembentukan Badan Penyelesaian Konsumen Pada Pemerintah Kota Medan, Kota Palembang, Kota Jakarta Pusat, Kota Jakarta Barat, Kota Bandung, Kota Semarang, Kota Yogyakarta, Kota Surabaya, Kota Malang,dan Kota Makassar. Pasal 3 pada Keppres ini mengatur "Biaya pelaksanaan tugas BPSK dibebankan kepada Anggaran Pendapatan Belanja Negara dan Anggaran Pendapatan Belanja Daerah". Kemudian dikuatkan lagi dengan Keputusan Menteri Pedagangan dan Industri Nomor: 605/MPP/
Kep/8/2002 Tentang Pengangkatan Anggota BPSK pada Pemerintah Kota Makassar, Kota Palembang, Kota Surabaya, Kota Bandung, Kota Semarang, Kota Yogyakarta dan Kota Medan. Pada diktum ketiga diatur:

Kepada anggota Badan Penyelesaian Sengketa Konsumen sebagaimana dimaksud dalam Diktum PERTAMA diberikan Honorarium setiap bulan terhitung sejak tanggal pelantikan dengan ketentuan sebagai berikut:

a. Pembayaran Honorarium terhitung sejak pelantikan sampai dengan akhir DesemberTahun Anggaran 2002 dibebankan kepada DIP Proyek Pemberdayaan Perlindungan Konsumen Tahun Anggaran 2002 (Mata Anggaran 01.5203.B.5960) pada Direktorat Perlindungan Konsumen Direktorat Jenderal Perdagangan Dalam Negeri Departemen Perindustrian dan Perdagangan;

b. Pembayaran Honorarium Anggota Badan Penyelesaian Sengketa Konsumen terhitung mulai 1 Januari 2003 dibebankan kepada Anggaran Pendapatan dan Belanja Daerah (APBD) pada masingmasing Pemerintah Kota sebagaimana dimaksud dalam Diktum PERTAMA.

Perkembangannya dengan Keputusan Presiden nomor Keputusan Presiden No. 108 Tahun 2004 Tentang Pembentukan Badan Penyelesaian Sengketa Konsumen (BPSK) dan Keputusan Presiden No. 23 Tahun 2006 Tentang Pembentukan Badan Penyelesaian 
Sengketa Konsumen (BPSK) yang mengesahkan berdirinya BPSK di Kabupaten/ Kota: Pada Tahun 2004 di "Pemerintah Kota Kupang, Kota Samarinda, Kota Sukabumi, Kota Bogor, Kota Kediri, Kota Mataram, Kota Palangkaraya dan pada Kabupaten Kupang, Kabupaten Belitung, Kabupaten Sukabumi, Kabupaten Bulungan, Kabupaten Serang, Kabupaten Ogan Komering Ulu dan Kabupaten Jeneponto, ditambah tahun 2006 di pemerintah Kota Pekalongan, Kota Parepare, Kota Pekanbaru, Kota Denpasar, Kota Batam, Kabupaten Aceh Utara dan Kabupaten Serdang Bedagai.

Kedua Keputusan Presiden tersebut pada diktum ke tiga mengatur Biaya pelaksanaan tugas BPSK dibebankan kepada Anggaran Pendapatan dan Belanja Daerah, hal ini sangat berbeda dengan dua Keppres sebelumnya yang masih memberikan beban terhadap APBN dalam rangka pelaksanaan tugas BPSK. Dengan demikian sudah seharusnya sebelum pembentukan BPSK yang pengesahannya dilakukan oleh Presiden di berikan payung hukum melalui "Peraturan Daerah" hal ini untuk menguatkan institusi ini sendiri, sehingga pada pelaksanaanya yang dibebankan dengan anggaran daerah benarbenar menjadi "Badan" yang keberadaannya menyesuaikan dengan otonomi daerah meskipun hanya bersifat 'small court". Terlebih urusan anggaran yang selama ini menjadi alasan tidak berdirinya BPSK di Madura.

\section{Simpulan}

Konsumen di wilayah Madura juga merupakan bagian dari warga negara di Indonesia yang berhak atas perlakuan yang sama sebagai perwujudan perlindungan terhadap hak asasi manusia berdasarkan Pasal Pasal 28 D butir (1) dan pasal 28 I butir (4) UUD RI Tahun 1945

Kebijakan terkait perlindungan konsumen pasca di undangkannya UUPK nomor 8 Tahun 1999 di wilayah Madura masih terbatas pada usaha yang bersifat preventif yaitu berupa pengawasan melalui operasi pasar oleh dinas terkait dan sosialisasi perlindungan konsumen berbentuk penyuluhan dan brosur menjadi konsumen cerdas.

Model pengaturan hukum yang dapat menjadi dasar bagi pendirian BPSK di Madura dapat diawali dengan membuat "Peraturan Daerah" tentang perlindungan konsumen, hal ini untuk memberikan kepastian hukum bagi keberadaan BPSK terutama berkaitan dengan masalah pendanaan operasional lembaga, selanjutnya baru diusulkan kepada Presiden Republik Indonesia untuk kepentingan pengesahan lembaganya.

Perwujudan perlindungan konsumen sebagai pemenuhan hak asasi manusia di wilayah Madura sudah seharusnya berlandaskan nilai keadilan dan perlindungan bagi masyarakat Madura, oleh karenanya program legislasi daerah perlu merespon urgensi pembentukan BPSK di Madura. 


\section{DAFTAR PUSTAKA}

\section{Buku}

Jimly Asshiddiqie \& M.Ali Safa'at, 2012,

Teori Hans Kelsen Tentang Hukum, Konstitusi Press, Jakarta.

Bambang Sunggono, 2006, Pengantar

Metode Penelitian Hukum, Rajawali, Jakarta.

Zulham, 2013, Hukum Perlindungan

Konsumen, Kencana Prenada Media Group, Jakarta.

\section{Jurnal}

Purwadi, Ari, 2001, Model Penyelesaian Sengketa Konsumen di Indonesia, Jurnal Yustika, Volume 4 No. 2, Media Hukum dan Keadilan, Fakultas Hukum Universitas Surabaya.

Euis Soliha, 1999, Peranan Konsumen, Produsen dan Pemerintah dalam Mewujudkan Perlindungan Konsumen, Volume 31 No. 5, Jurnal Gema Stikubank, Sekolah Tinggi Ilmu Ekonomi Stikubank Semarang.

T.Wulandari, Bernadetta 2006, Badan Penyelesaian Sengketa Konsumen (BPSK)

Sebagai Alternatif Upaya Penegakan

Hak Konsumen di Indonesia, Jurnal Hukum Gloria Juris, Volume 6, No. 2, Fakultas Hukum Universitas Katolik Atma Jaya Jakarta.

\section{Peraturan Perundang-undangan}

Undang-Undang Dasar Republik Indonesia
Undang-undang Nomor 8 Tahun 1999 tentang Perlindungan Konsumen.

Undang-undang Nomor 23 tahun 2014 tentang Pemerintahan Daerah.

Keputusan Menteri Perindustrian dan Perdagangan Nomor 301/MPP/ Kep/10/2001 tentang Pengangkatan dan Pemberhentian Anggota dan Sekretariat Badan Penyelesaian Sengketa Konsumen.

Surat Keputusan Menteri Perindustrian dan Perdagangan Nomor. 350/MPP/ Kep/12/2001 tentang Pelaksanaan Tugas dan Wewenang Badan Penyelesaian Sengketa Konsumen.

Keputusan Menteri Perindustraian dan Perdagangan Nomor 419/MPP/ Kep/4/2001 tentang Pembentukan Tim Penyeleksi Penetapan Anggota Badan Penyelesaian Sengketa Konsumen.

\section{Naskah Internet}

Koran Madura, Kemenag Belum mampu Mendeteksi, http://www.koranmadura. com/kemenag-belum-mampumendeteksi/.

Tesis Hukum, Pengertian, Perlindungan Hukum Menuru Para Ahli, http://tesishukum.com/pengertianperlindungan-hukum-menurut-paraahli/. 